\title{
Metal Concentrations in Snow Samples in an Urban Area in the Po Valley
}

\author{
C. Telloli \\ Italian National Agency for New Technologies, Energy and Sustainable Economic Development (ENEA), \\ Technical Unit for Environmental Assessment Models, Methods and Technologies (UTVALAMB), Air Quality \\ Laboratory (AIR), Bologna, Italy \\ Email: chiara.telloli@enea.it
}

Received 14 July 2014; revised 12 August 2014; accepted 5 September 2014

Copyright (C) 2014 by author and Scientific Research Publishing Inc.

This work is licensed under the Creative Commons Attribution International License (CC BY). http://creativecommons.org/licenses/by/4.0/

c) (i) Open Access

\section{Abstract}

This study shows a chemical and morphological characterization of snow samples collected near crossroads of urban area of Ferrara and near the Technological College of University of Ferrara (Italy) during three important snowfalls. The field campaigns were carried out in the eastern part of Po Valley (Italy) in winter 2009-2010. The chemical composition of melted snow was compared with analyses of the same filtered samples of melted snow so as to give the composition of particles smaller than a few $\mathrm{nm}$. The metal concentrations in the aerosol particles were analyzed with ICP-MS and IC methodologies, while the morphological features were described by SEM-EDS analyses. The results showed that snow samples were characterized by important amounts of allumo silicates with dimensions larger than $0.45 \mu \mathrm{m}$, from resuspension of the local soil, and IC analysis confirmed the anthropogenic pollution of the snow. Six main particles were classed and recognized: silica, carbonate, allumo silicate, sodium chloride and organic compounds, including biogenic materials and pollen (agricultural aerosols which are composed for $92 \%$ of single particles and for the remaining $8 \%$ of agglomerations of particles). We present here initial data on heavy metals in snow collected in Ferrara. They were obtained by analyzing fresh snow deposited during three snowfall events in December 2010, February and March 2011. The analyses were performed by the inductively coupled plasma mass spectrometry (ICP-MS), ion chromatography (IC) and scanning electron microscopy (SEM-EDS).

\section{Keywords}

Air Quality, Snow, SEM-EDS, IC, ICP-MS

\section{Introduction}

Studies of the chemical characterization of the snow to quantify the contribution of natural or anthropogenic 
sources have increased in recent years [1]-[6].

In the last period, many of the Italian urban areas have recorded numerous and repeated events exceeding the limit concentrations of particulate $\left(\mathrm{PM}_{10}\right)$ for the environment and for the protection of human health [7] [8]. The high presence of particulate matter in the atmosphere produces effects on health [9] [10] and the deterioration of monuments [11] [12]. Epidemiological and environmental studies have shown that these negative effects are related with size and chemical composition of the particles [13] [14], especially with the presence of trace elements [15]. Trace elements occur naturally in the Earth's environment in low concentrations. However, human activity, such as industry, fuel combustion, metal smelting, agriculture, can result in concentrations of some elements greater than their natural background levels [16]. This can alter the rate at which elements are transported into the atmosphere within air masses, moving through ecosystems with adverse effects for the environment and human health depending upon their toxicity [15] [16].

Aerosol found in urban areas represents a mixture of primary particles emitted from several sources, which could be anthropogenic and/or natural.

Aerosol particles are important carriers of metals, some of which possess toxic properties. The major metals and trace elements in the aerosol may result from: crustal origin form resupsended dust could be Ca, Mg, Fe and $\mathrm{Al}$ [17] [18]; Sr could replace Ca in minerals like calcite and gypsum and Rb, Li and Cs can be constituent of aluminum silicate minerals [19]; Ni, Cr, Mn, $\mathrm{Cu}$ and $\mathrm{Zn}$ might have originated from industrial activities [18]. Ni associated with V could be associated to fuel use, in particular petroleum coke or fuel oil from cement and ceramics industries [20]-[22]; coal combustion processes could be $\mathrm{Al}$, Fe and $\mathrm{Ca}$ [23]; K, Cu and $\mathrm{Zn}$ could be products of refuse incineration [24]; products of oil combustion include $\mathrm{Mn}, \mathrm{Fe}$ and $\mathrm{Pb}$ [25] and products of refuse oil burning include $\mathrm{Pb}, \mathrm{Cd}$ and V [26]-[28]; Pb, Fe and Zn could be products of vehicle exhausts [29]; Ca and $\mathrm{Zn}$ are often added to motor oil [30]; wood burning processes result in generation of $\mathrm{K}$ for domestic and commercial purposes [18] [31]; Cu, Zn, Sn and Sb could be products of tire and brake abrasion [21] [32]-[35]; the important uses of $\mathrm{Cd}$ are as alloys, in electroplating industry, in pigments, as stabilizers in polyvinyl plastics and in Ni-Cd batteries [36]; sodium chloride ( $\mathrm{NaCl})$ could be considered to be a pollutant from the de-icing agents used to secure the road condition [37].

It is important to know the metals and trace elements present in the atmosphere to better understand the sources of these pollutants and implement mitigation plans in the areas most subject to pollution, especially during winter season, in which weather conditions facilitate the stationing of pollutants.

Some researchers have shown that it is not negligible that the contaminants accumulated during the winter season can have an impact on natural resources during and after the melting of snow in spring [38]. In areas of permanent snow and glaciers, contaminants may be subject to deep burial resulting in inclusion in the layers of ice [39] [40]. Snowpits and ice cores retrieved from high-latitude/high-elevation glaciers are an ideal archive for documenting the modern and past composition of the atmospheric chemistry because they provide high-resolution, well-preserved, multiparameter archives of the atmospheric signature from remote areas worldwide. Previous investigations of trace elements in snow and ice from Greenland [41]-[44], the Canadian Arctic [45]-[47] and Antarctic [48]-[51] have enhanced our understanding of the current status of the atmosphere, past anthropogenic perturbations, and the response of these areas to changing emissions from industrial activities in Eurasia, North America and central Asia. In recent studies, the concentrations of trace elements were measured in the snow at high altitudes in eastern Tien Shan [52] [53], eastern Pamirs Mountains Muztagh Ata in northern China [54]-[56], on Mount Everest in the Himalayas [57]-[59], in the Scottish mountains [60], in America [61] and in the Italian Alps [61]-[73]. From all these studies it is understandable that the concentrations of some trace elements vary from area to area.

In regions with cold climatic conditions, snow surveying has become a major environmental research topic [74]-[77]. According to Engelhard et al. (2007) [78], snowflakes accumulate more pollutants from the atmosphere than raindrops because of their larger surface area and slower fall velocity.

Snow acts as a natural filter for various chemical elements and particles, especially those originating from anthropogenic activities (e.g., industry, road traffic) [79]. As suggested by Viskari et al. (1997) [80] snow appears to be a good collector of organic and inorganic pollutants from the atmosphere and can be used to monitor local airborne pollution from road traffic. Recently, deposition of polyaromatic hydrocarbons (PAH) [81], heavy metals [72] [82]-[88], platinum-group elements (Rh, Pt, Pd) [86] and concentrations of particles in different size fractions [73] [89] on snow have been reported.

Snow sampling can be applied to assess the load of anthropogenic emissions on local [86] [90] and regional 
scales [85] [91].

Several studies have emphasized the importance of knowing the falling snow to recognize both the aerosol particles and the phases of volatile organic compounds from the atmosphere [92] [93]. These empirical and theoretical studies suggest that the snow has a great efficiency in both maintaining the particles that are the gaseous phases of organic compounds with respect to the rains. For this reason, the snow plays an important role in contamination of the environment [69].

Results presented in this paper showed a chemical and morphological characterization of snow samples collected near crossroads of urban area of Ferrara and near the Technological College of University of Ferrara (Italy) during three important snowfalls and analyzed by SEM-EDS, ICP-MS and IC techniques. Snow was used as a sampling medium because it is an efficient scavenger of air pollutants, and usually remains on the ground for sampling after the event and snowmelt contaminates soil [6].

Several analytical techniques have been used in the past for the determination of trace elements in snow and ice [1] [94] and ICP-MS has emerged as a useful technique owing to its multi-element capability, high detection power and low sample consumption [95]. The analysis of the chemical composition of snow provides useful information on aerosol chemistry and long-range distribution patterns of anthropogenic substances emitted into the atmosphere [96]-[101]. Concentrations of dissolved elements in melted and filtered snow may be used to estimate deposition during winter [102]. However, total deposition can be seriously underestimated if particulates within the snow are omitted [85] [90].

The objectives of the work presented in this paper were: to analyze the metal concentration in snow collected near and far the crossroads in an urban area in Ferrara and in a rural area in Codigoro; to find out its correlation with the fine particle fraction that stay suspended in melted snow after filtration; to understand if anthropogenic or natural sources have a predominant role in snow pollution.

\section{Methods}

\subsection{Field Site}

Several measurements campaigns were carried out during winter 2009-2010 in the city of Ferrara (north-east of Italy) (Figure 1). The sampling areas are located in the east part of Emilia Romagna in the Po Valley. The first

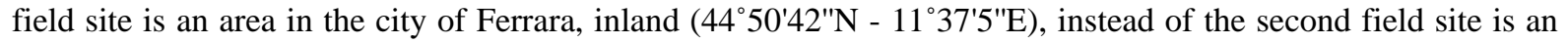
area in the suburb of Ferrara near the Adriatic Sea called Codigoro $\left(44^{\circ} 50^{\prime} 0^{\prime \prime} \mathrm{N}-12^{\circ} 7^{\prime} 0 " \mathrm{E}\right)$.

Four sampling areas were selected in Ferrara: Sample 1 = overpass near a main street; Sample 2 = overpass behind the University; Sample 3 = parking; Sample 4 = garden. These areas were located near a main road, for this reason it can be possible to find elements of anthropogenic pollution from vehicular traffic.

Two sampling areas were selected in Codigoro: Sample $5=$ urban area; Sample $6=$ rural area.

The first area in Codigoro is an urban area, for this reason it can be possible to find elements of anthropogenic pollution from vehicular traffic, as in the samples collected in Ferrara. Instead of the second area in Codigoro is a rural area, and elements of anthropogenic sources it can be difficult to find.

In general, the soil is a silt clay soil, made from terrigenous sediments transported and deposited by the river

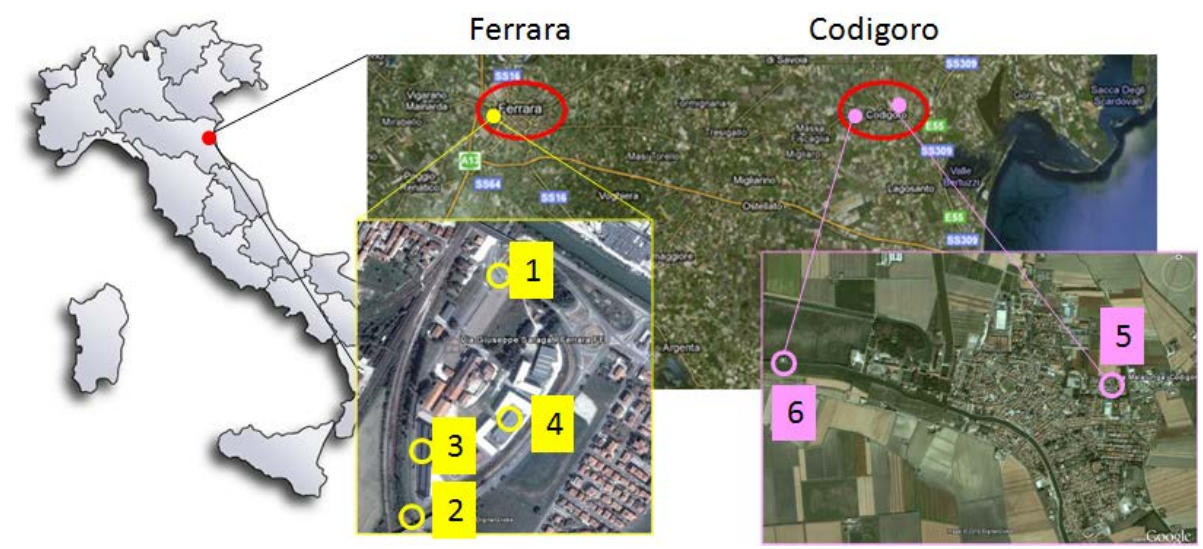

Figure 1. Map of the sampling site. 
Po (Bianchini et al., 2001) [103]. The rural area is far enough from the Adriatic Sea and therefore the contribution of particulate matter from sea spray is negligible.

\subsection{Sampling}

All the campaigns were carried out after and during the snowfall in December 2009, February 2010 and March 2010. The main goal was to investigate the spatial and temporal distribution of trace elements in an urban and rural area. The meteorological data (temperature, humidity, wind direction and wind velocity) were provided by ARPA Emilia Romagna weather station. For the city of Ferrara the nearest meteorological station is "Ferrara urban”, which is $26 \mathrm{~m}$ u.s.l. (Lat: 44.832498 - Long: 11.621138 26). For Codigoro the nearest meteorological stations are in Copparo, which is $30 \mathrm{Km}$ far from the sampling area (1 m u.s.l.; Lat: 44.916303 - Long: 11.821301) and in Volano, which is only $15 \mathrm{Km}$ from the sampling area but it is located near the Adriatic Sea (1 m u.s.l.; Lat: 44.812868 - Long: 12.250367).

The sampling during the snowfall in December was carried out in the morning of the 21/12/2009, two days later the snowfall. The wind parameters had allowed speed of $2 \mathrm{~m} / \mathrm{s}$, high values of relative humidity $93 \%$, low temperature (max: $-5^{\circ} \mathrm{C}$, min: $-7^{\circ} \mathrm{C}$ ) and pressure $1015 \mathrm{mb}$. The data of the monitoring station of ARPA Ferrara shown a high concentration of $\mathrm{PM}_{10}$ and $\mathrm{PM}_{2,5}$ in day of the sampling (21 December 2009, Figure 3). In Ferrara $\mathrm{PM}_{10}=79 \mu \mathrm{g} / \mathrm{m}^{3}$ and $\mathrm{PM}_{2,5}=56 \mu \mathrm{g} / \mathrm{m}^{3}$ (Ferrara CorsoIsonzo monitoring station far $1.8 \mathrm{Km}$ from the sampling site in Ferrara); near Codigoro $\mathrm{PM}_{10}=55 \mu \mathrm{g} / \mathrm{m}^{3}$ and $\mathrm{PM}_{2,5}=45 \mu \mathrm{g} / \mathrm{m}^{3}$ (Gherardi monitoring station far $15 \mathrm{Km}$ from Codigoro).

The sampling during the snowfall in February was carried out in the morning of the day 01/02/2010.The value of wind speed was $3 \mathrm{~m} / \mathrm{s}$. High values of relative humidity $71 \%$ and low temperatures (max: $2^{\circ} \mathrm{C}, \min :-7^{\circ} \mathrm{C}$ ) and pressure $1013 \mathrm{mb}$. The data of the monitoring station of ARPA Ferrara shown a low concentration of PM 10 and $\mathrm{PM}_{2,5}$ in day of the sampling (01 February 2010, Figure 3). In Ferrara $\mathrm{PM}_{10}=48 \mu \mathrm{g} / \mathrm{m}^{3}$ and $\mathrm{PM}_{2,5}=35$ $\mu \mathrm{g} / \mathrm{m}^{3}$; in suburb $\mathrm{PM}_{10}=37 \mu \mathrm{g} / \mathrm{m}^{3}$ and $\mathrm{PM}_{2,5}=33 \mu \mathrm{g} / \mathrm{m}^{3}$.

The sampling during the snowfall in March was carried out in the morning of the day 10/03/2010. The value of wind speed was $9 \mathrm{~m} / \mathrm{s}$. High values of relative humidity $91 \%$ and low temperatures $\left(\max 1{ }^{\circ} \mathrm{C}\right.$, $\min 0{ }^{\circ} \mathrm{C}$ ) and pressure $1010 \mathrm{mb}$. The data of the monitoring station of ARPA Ferrara showed a low concentration of $\mathrm{PM}_{10}$ and $\mathrm{PM}_{2,5}$ in day of the sampling (10 March 2010, Figure 3). In Ferrara $\mathrm{PM}_{10}=22 \mu \mathrm{g} / \mathrm{m}^{3}$ and $\mathrm{PM}_{2,5}=13 \mu \mathrm{g} / \mathrm{m}^{3} ;$ in suburb $\mathrm{PM}_{10}$ and $\mathrm{PM}_{2,5}$ not detected.

The backward trajectories (software online NOAA HYSPLIT MODEL - GDAS Meteorological Data) shown that the wind direction was from North in the first two sampling and from the east during the thirty sampling (Figure 2(a) 21/12/2009, Figure 2(b) 01/02/2010, Figure 2(c) 10/03/2010).

The instruments used for sampling were simple plastic tins, previously cleaned with MilliQ ${ }^{\circledR}$ water, with double-sealed cap.

The graphs in Figure 3 showed the concentrations of $\mathrm{PM}_{10}$ and $\mathrm{PM}_{2.5}\left(\mu \mathrm{g} / \mathrm{m}^{3}\right)$ in Ferrara and Codigoro before and after the sampling days (ARPA Emilia Romagna).

Only the samples in December 2009 were collected during a high pollution event, in which the contributions of $\mathrm{PM}_{10}$ and $\mathrm{PM}_{2.5}$ exceed the limit value $\left(50 \mu \mathrm{g} / \mathrm{m}^{3}\right.$ - D.M. 2 aprile 2002, n.60) in Ferrara $\left(\mathrm{PM}_{10}\right.$ and $\left.\mathrm{PM}_{2.5}\right)$ and in Codigoro only for $\mathrm{PM}_{10}$.

The concentrations of $\mathrm{PM}_{10}$ and $\mathrm{PM}_{2.5}$ during the snow event in February were lower the limit value (Figure 3(b)), because the snow event started the day before the sampling (31 January 2010) but with a mixture of snow and rain. This could have reduced the concentrations of particulate matter in the atmosphere. The snow mixed with rain melted in contact with the ground dispersing the collected particulate, which was present in high concentration before the snow event. During the last snow event, March 2010, the concentrations of PM $\mathrm{PM}_{10}$ and PM 2.5 were already under the limit value before the sampling (Figure 3(c)).

\section{Analysis}

After collection, the snow samples were transported in a refrigerated cooler to UNIFE laboratory in Ferrara and stored under refrigeration until microscopy and chemical analysis was performed [104].

\subsection{SEM-EDS Analysis}

The snow samples were used for SEM-EDS analysis to characterize the shape and morphology and the elemental 
NOAA HYSPLIT MODEL

Backward trajectories ending at 0000 UTC 21 Dec 09

GDAS Meteorological Data

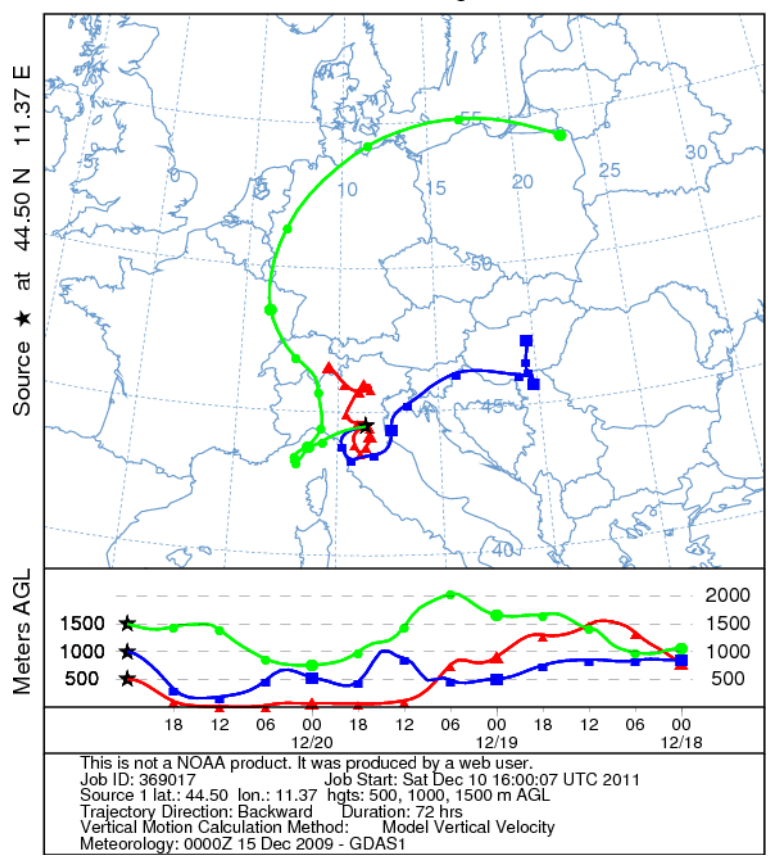

(a)
NOAA HYSPLIT MODEL

Backward trajectories ending at 0000 UTC 01 Feb 10 GDAS Meteorological Data

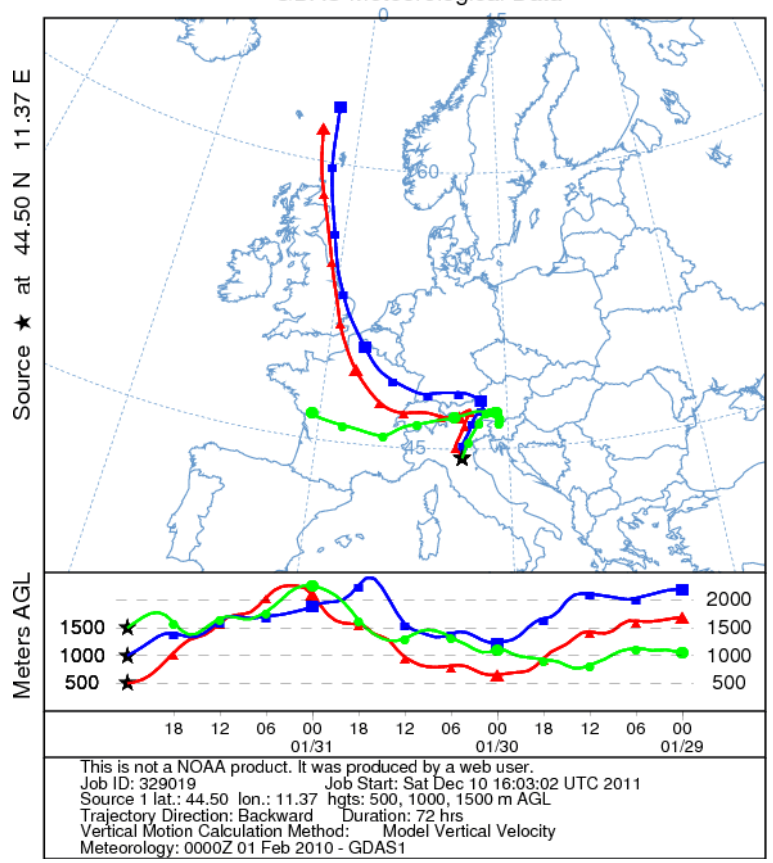

(b)

NOAA HYSPLIT MODEL

Backward trajectories ending at 0000 UTC 10 Mar 10

GDAS Meteorological Data

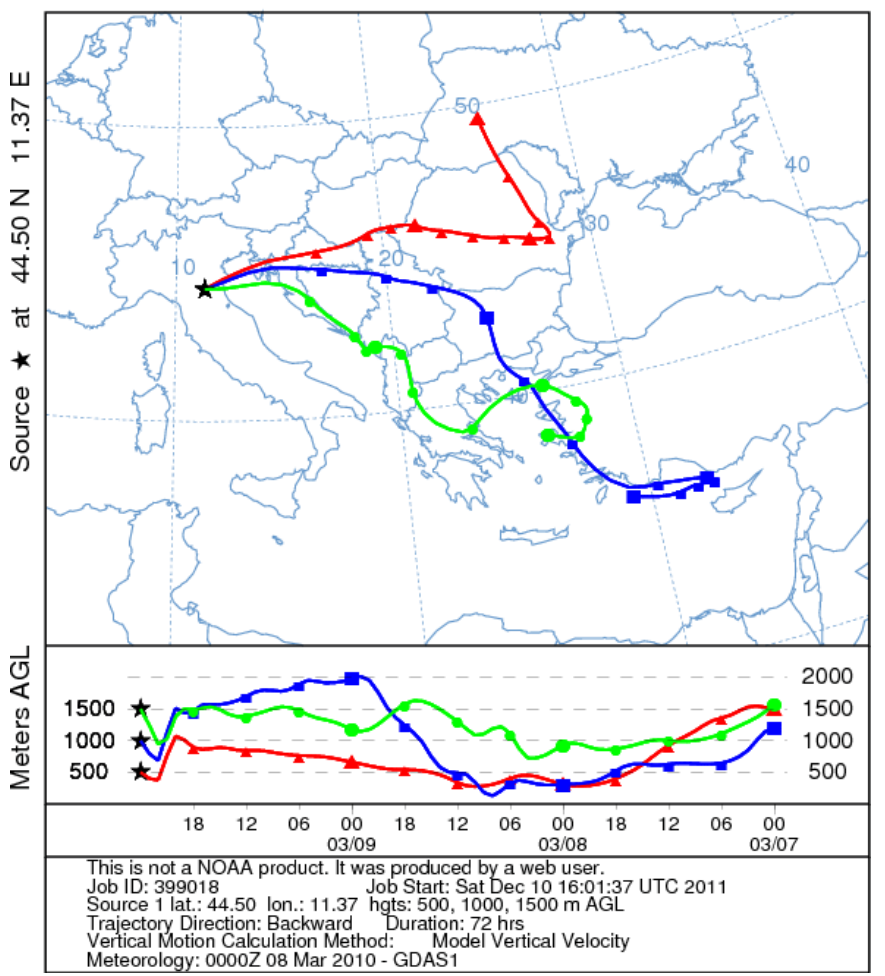

(c)

Figure 2. Images of backward trajectories (72 hours) representative the direction of the winds during the sampling campaigns: 21/12/2009 (a), 01/02/2010 (b), 10/03/2010 (c). 


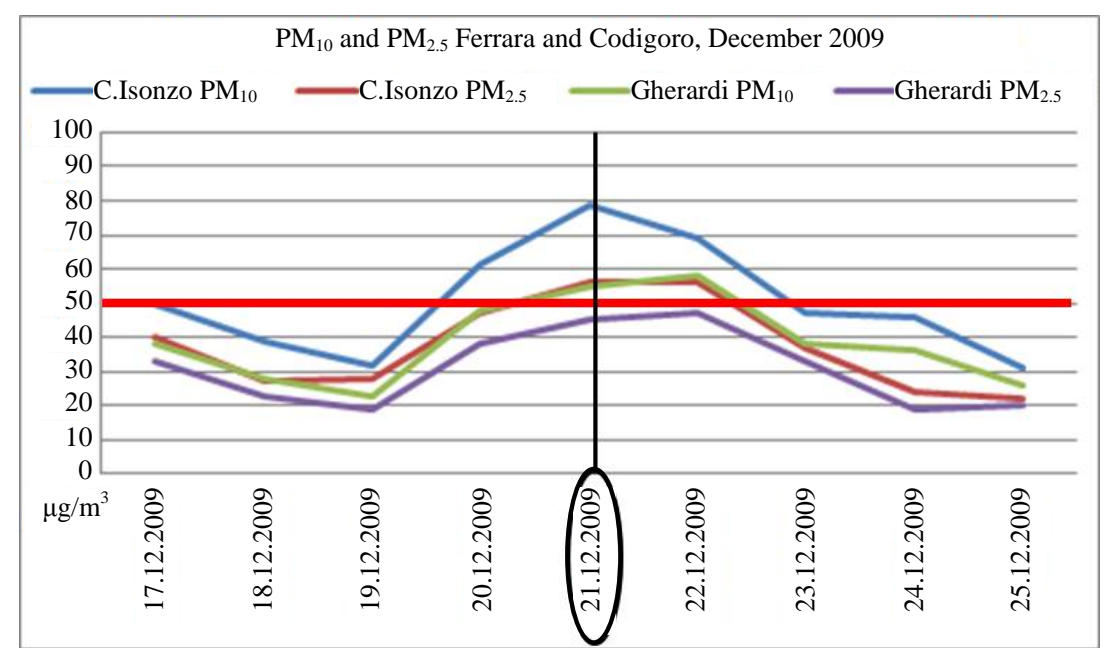

(a)

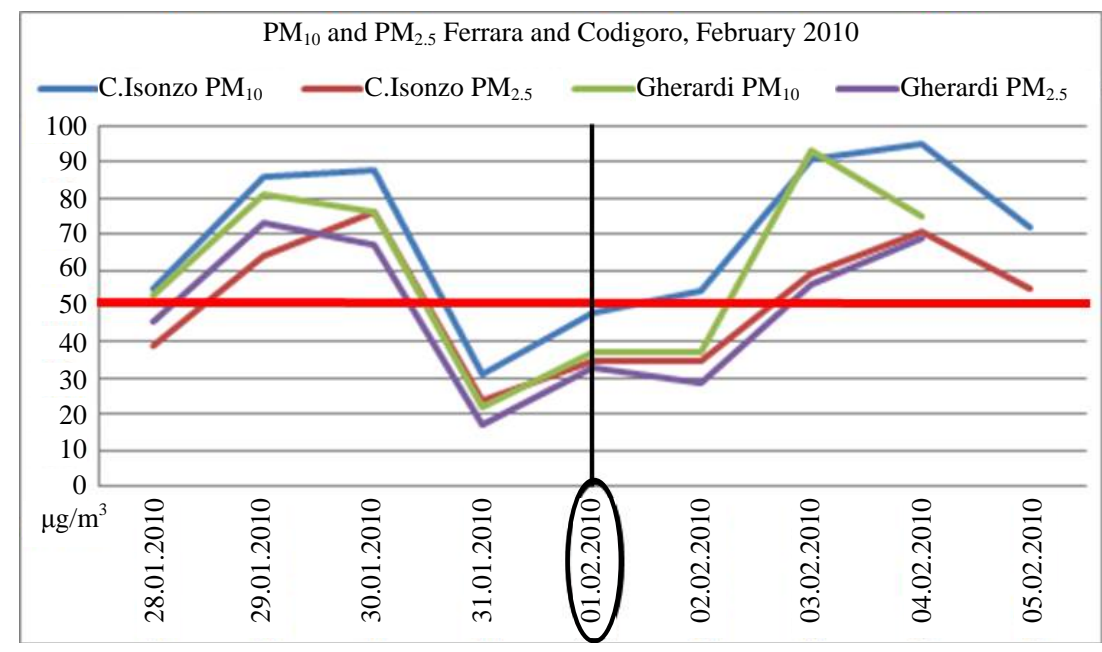

(b)

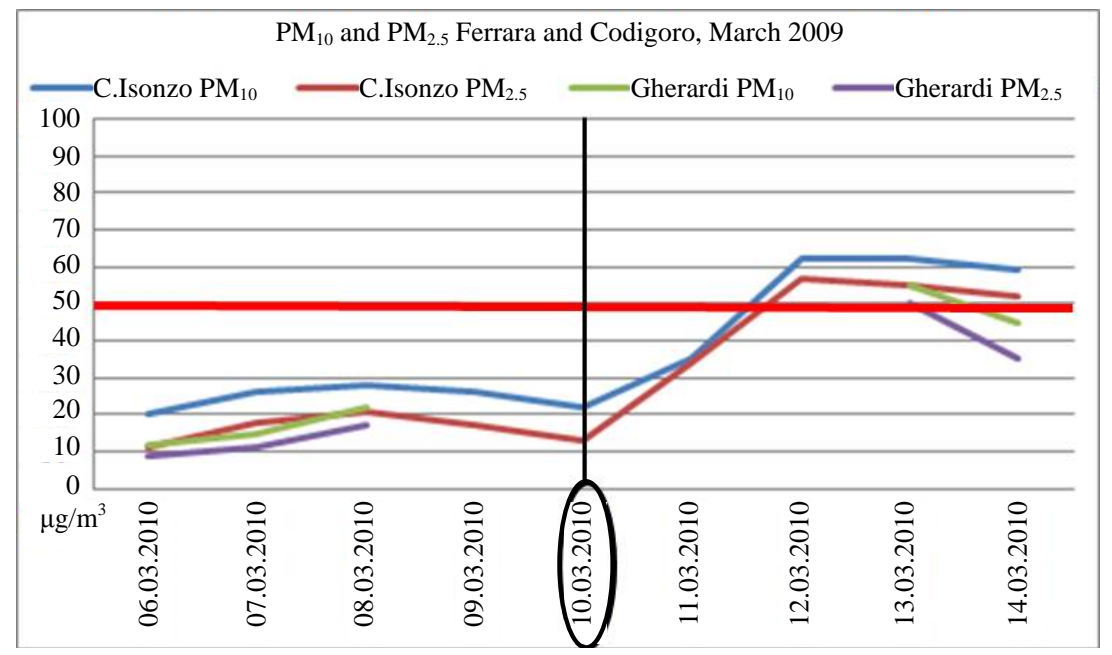

(c)

Figure 3. $\mathrm{PM}_{10}$ and $\mathrm{PM}_{2.5}$ concentration in the monitoring station near Ferrara (C. so Isonzo) and Codigoro (Gherardi) during the snow events. (a) December 2009, (b) February 2010, (c) March 2010. 
composition of aerosol particles collected. Morphological characteristics, size and elemental analysis of individual particles were performed with a Scanning Electron Microscopy (SEM) (Zeiss EVO 40) equipped with an Energy Dispersive X-ray Spectrometer (EDS) (INCA 300 OXFORD) for X-ray microanalysis. The particle size and the surface morphology of sampled aerosol particles were investigated in high resolution mode (up to $20.000 \mathrm{X}$ ) with a working voltage of $20 \mathrm{kV}$ which correspond to the detection limit of $1 \mu \mathrm{m}$ particle size. The analyses were qualitative and were performed in the manually mode. SEM-EDS is often employed to identify airborne particulate deposits and biological materials [105]. In EDS, the X-ray detector measures the number of emitted X-rays as a function of their energy. Since elements have a characteristic energy, the EDS spectrum can be used to identify the quantity of elements present [106]. EDS technique is able to characterize the chemical composition of particles whose diameter is greater than 1 micron [107]. The Scanning Electron Microscopy is a technique employed in numerous atmospherically studies [104] [107]-[112]. SEM-EDS measurements were performed on an adhesive support. Portions of the substrate were mounted on aluminum support SEM "stubs" with double-sided tape which had a conductive graphite-based. The samples were then coated with a thin layer of gold (coating) film by electric arc high vacuum method and then analyzed by SEM.

\subsection{ICP-MS Analysis}

Chemical analysis has carried out by Inductively Coupled Plasma Mass Spectrometry (ICP-MS). Samples analysis has been performed with a Thermo Electron Corporation Xeries spectrometer, with a collision/reaction cell $\left(C C T^{E D}\right)$ for the reduction/exclusion of main polyatomic and isobaric interferences. This technique is suitable for revealing in solutions most of the elements present in the periodic table. Results are expressed as a concentration in $\mu \mathrm{g} / \mathrm{m}^{3}$. In the fine tuning of the procedure for the samples treatment for ICP-MS analysis the samples were prepared with a solution of standard (Rh - Re $100 \mathrm{ppb}$ ). Two different kinds of samples were prepared for each samples of snow, one represented the solution sampled, and one represented the solution filtered with a filter $0.45 \mu \mathrm{m}$ porosity, to analyze only the fine particles. All samples were analyzed by ICP-MS to determine the major, minor and trace elements. The samples collected were dissolved by acid digestion in a hotplate open system in different steps with $\mathrm{HF}, \mathrm{HNO}_{3}$ and $\mathrm{H}_{2} \mathrm{O}_{2}$. The Limits of Detection of this technique is the minimum significant concentration. This analysis allows to recognize the geochemical fingerprint of the snow and to provide markers to refer the local origin and to identify anomalies related to the contributions of transboundary particles.

\subsection{IC Analysis}

For the IC analysis we used the ion chromatograph Dionex ICS2000, which uses of an eluent of carbonate-bicarbonate. The anions are separated by an ion-exchange resin, low-capacity and highly basic and direct in a strong acid cation exchanger (suppressor), where they are converted into an acid form with high conductivity and the eluent is transformed into carbonic acid with weak conductivity. Therefore, the anions are measured for conductometry and compared with the standards on the basis of the retention times. The quantization is done by measuring the peak area or height. For IC analysis, $100 \mathrm{cc}$ of each snow solution samples were injected in the instrument and analyzed.

\section{Results and Discussions}

\subsection{Morphological Classification by SEM Analysis and Elemental Composition by SEM-EDS Microanalysis}

For each sample, high-resolution images of particles were obtained by SEM regulating the vacuum inside the instrument chamber. Several distinct particle shapes were observed on substrate, and they can be classified in four distinct categories: square particles (Figure 4(a)), rounded particles (Figure 4(b)), amorphous particles (Figure 4(c)), agglomerations of multiple amorphous particles (Figure 4(d)) [104]. The majority of particles were classified as amorphous particles ( 60\%), less as square particles $(\sim 20)$, rounded particles $(\sim 12 \%)$ and a minority as agglomerations of particles $(\sim 8 \%)$.

The composition of single particle was determined using EDS microanalysis which detected the presence of C, O, Na, Mg, Al, Si, P, S, Cl, K, Ca, Mn and Fe [113]. The chemical composition of the analyzed particles can be divided in two main categories: the first category of particles contains inorganic compounds, like silica (Figure 4(a)), carbonate (Figure 4(e)), allumo silicate (Figure 4(c)), amphibole (Figure 4(f)), ferrous particle (Figure 4(g)), 


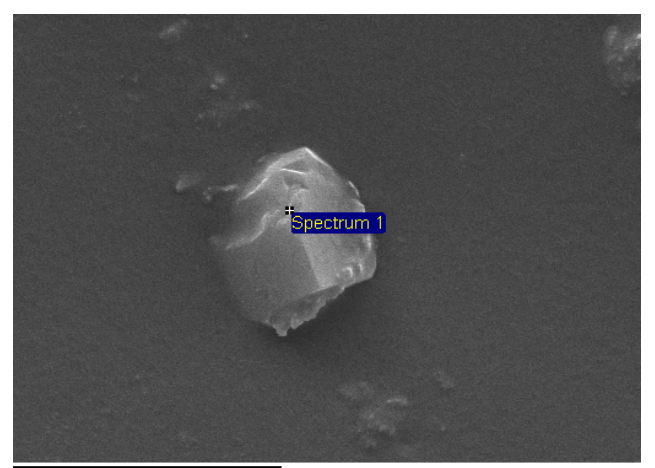

(a)

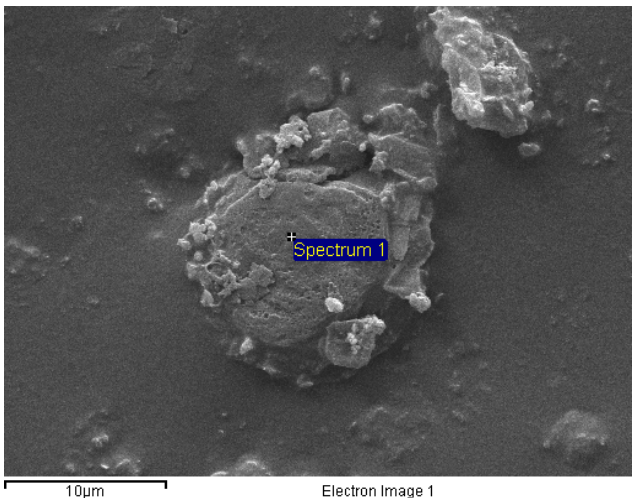

(c)

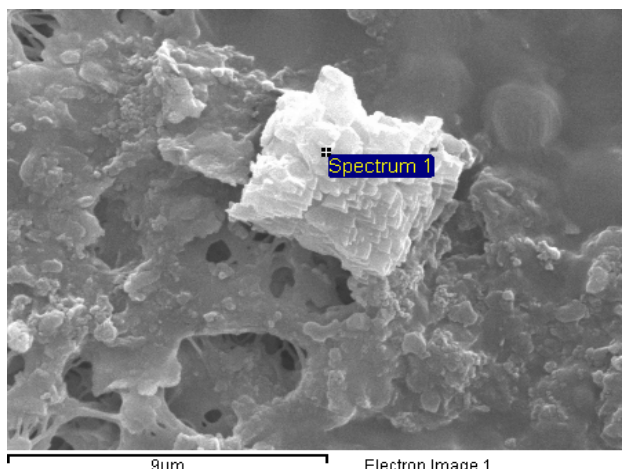

(e)

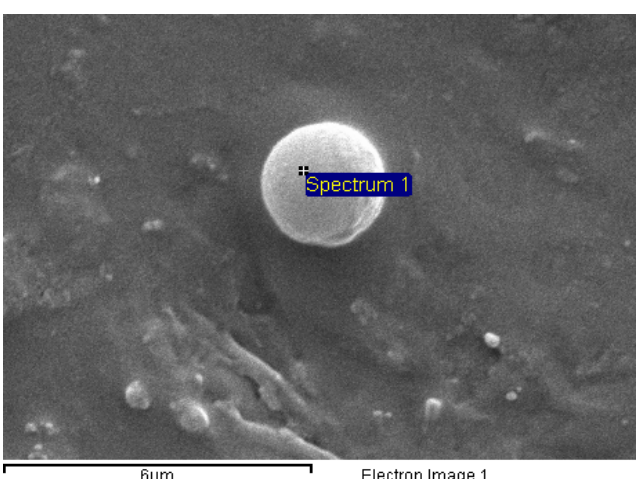

(b)

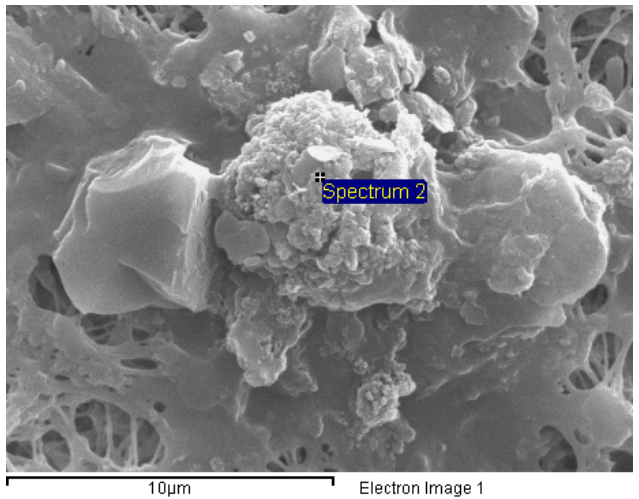

(d)

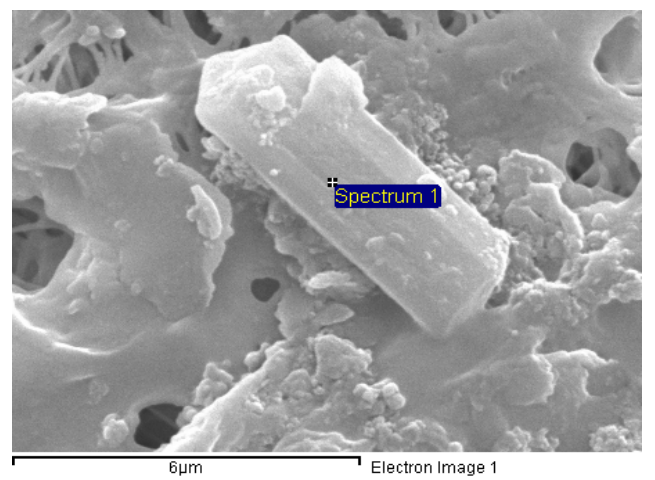

(f)

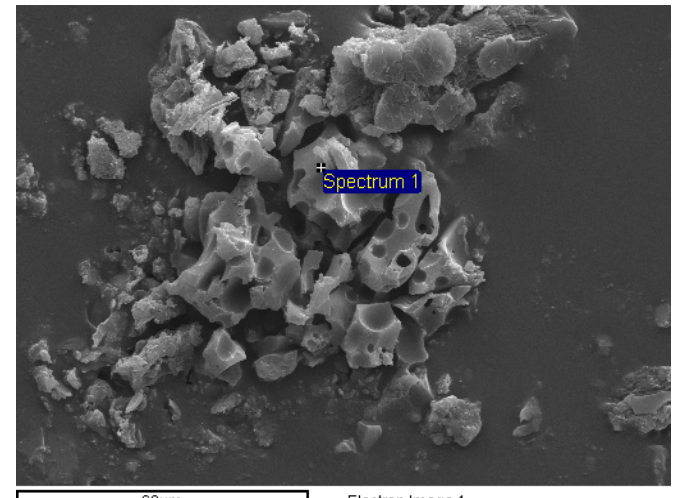

(g)

Figure 4. Images of representative particle shapes: square particles (a), round particle (b), amorphous particle (c) and (g), agglomerate (d), scalenohedral/rhombohedral (e), amphibole (f). 
micrometeorite (Figure 4(b)); the second category of particles contains smaller organic compounds, including biogenic materials and pollens.

The concentration of organic particles observed by SEM-EDS is not abundant (less than 5\%), respect the inorganic fraction ( $95 \%)$. These qualitative results allow comparing the chemical composition of the aerosol sampled by the snowfall. The SEM-EDS measurements also showed that particulate matter was dominated by particles with diameters greater than $2.5 \mu \mathrm{m}$.

Carbonates, silica and clay mineral were originated from soil erosion and its resuspension and they had the typical morphology of crustal mineral: carbonate crystalline (rhombohedral and scalenohedral morphology), allumo silicate lamellar, angular or rounded silica. The particles with original morphology indicate that the sources are local, while the particles with rounded morphology suggest that the particles travelled and their angular morphology was eroded by wind or snow.

Figure 5 shows the chemical composition of particles analyzed by SEM-EDS. In all samples allumo silicate is the most abundant component of the inorganic fraction, followed by $\mathrm{NaCl}$, silica, carbonate and only a minority were organic materials.

In December samples, the clay mineral particles were prevalent. This lamellar morphology suggested a local source. Few quartz and calcite particles were observed. The rhombohedra and scalenohedra morphology of calcite particles suggested that they were formed through chemical and physical processes in the presence of water, so called: a chemical precipitation source.

In February and March samples, the inorganic particles were prevalent clay minerals with a lamellar morphology produced from local sources. Few quartz with square morphology, calcium carbonate particles and ferrous amorphous particles were also observed. Figure 4(b) shows typically rounded particles that could be a micro meteorite [114] [115]. The low presence of organic particles observed in all samples of different snow events were characterized by crushed pollen, paradoxically these pollens are typical of arid environment.

\subsection{Chemical Composition by ICP-MS Technique}

The snow samples were analyzed by ICP-MS. For sampling preparation see [73].

$\mathrm{Li}$ - Be - B - Cr - Co - Ni - Ga - As - Rb - Mo - Ag - Cd - Sb - Sn - Hg - Tl - Bi - U were under the detection limit, that indicates low concentration of metals. The precision of the measurements, in terms of their repeatability, was determined on snow samplescollected in Ferrara. The standard deviations of each trace elements determined in the sample (\%) are: $\mathrm{Al} \mathrm{0.3,} \mathrm{Fe} \mathrm{0.5,} \mathrm{V} \mathrm{0.5,} \mathrm{Mn} \mathrm{0.4,} \mathrm{Cu} \mathrm{0.3,} \mathrm{Zn} \mathrm{9,} \mathrm{Se} \mathrm{0.4,} \mathrm{Te} \mathrm{0.5,} \mathrm{Pb} \mathrm{0.2,} \mathrm{Ba} \mathrm{0.4,} \mathrm{Sr} \mathrm{0.5,}$ Ca 51, Mg 7, K 4, Na 25.

Chemical analysis and particles size analysis were obtained by analyzing the content of filtered samples. The filtered used was a PTFE filter with $0.45 \mu \mathrm{m}$ porosity.

Figure 6 shows the chemical composition of particles analyzed by ICP-MS. The graphs show the relationship between the filtered solution (filtered) and the real solution (suspended) for the main elements and metals analyzed by ICP-MS of the three snow events: December (A), February (B) and March (C).

Some elements are below the limit of detection $(<0.0001 \mathrm{ppm})$ in the filtered solution.

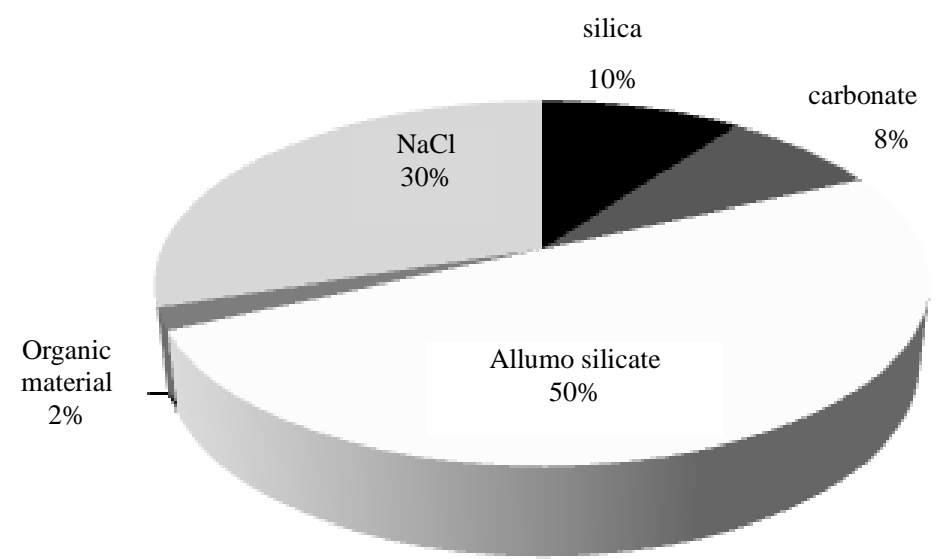

Figure 5. Chemical composition of the particles analyzed by SEM-EDS. 

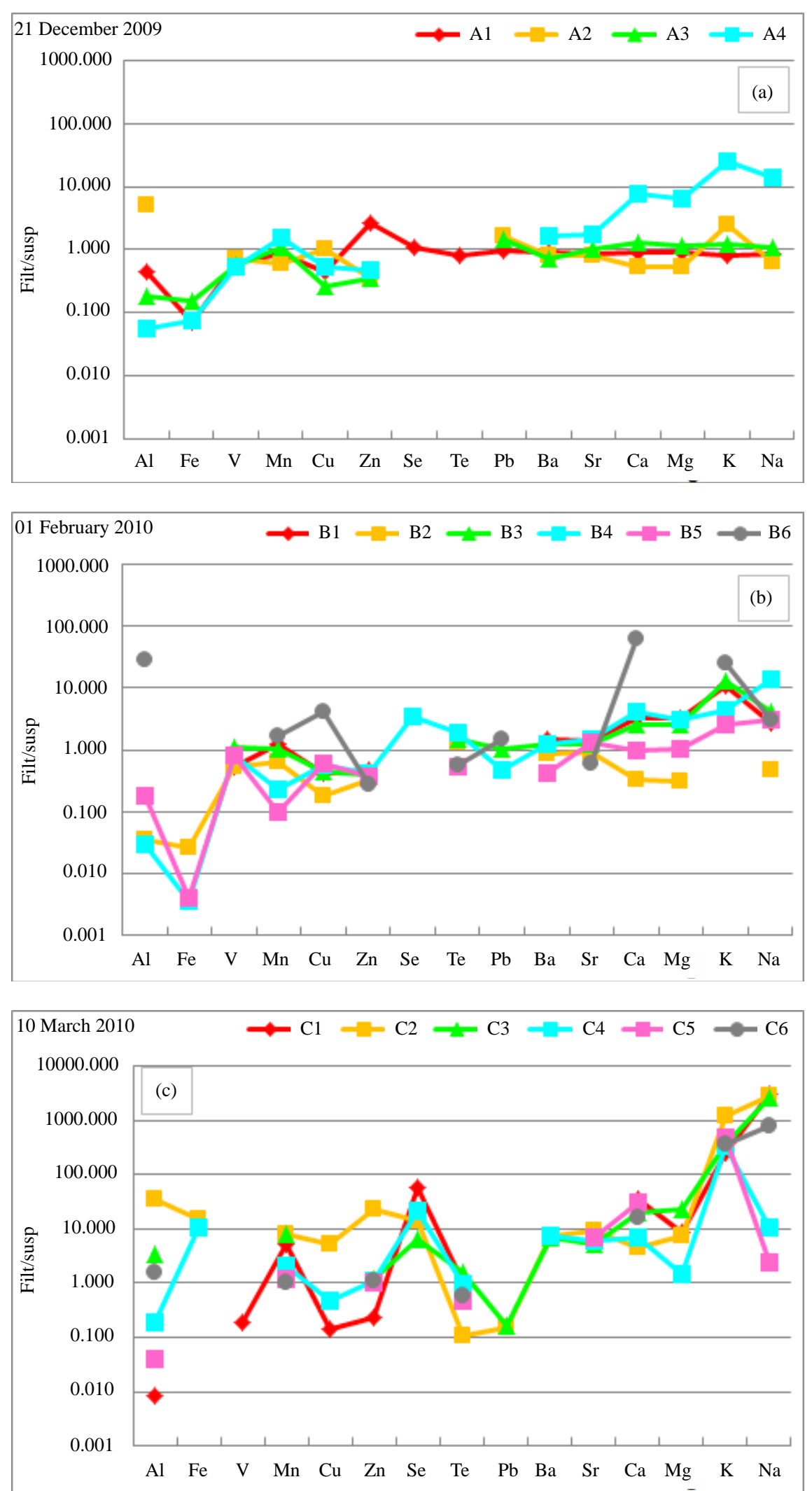

Figure 6. Chemical composition of particles analyzed by ICP-MS. Relationship between filtered and suspended: December (a), February (b) and March (c). 
The elements under the limit value 1 represent soluble particles or particles with dimension under $0.45 \mu \mathrm{m}$ (porosity of the filter).The difference between filtered and suspended indicates the size of the particles: ratio < 1 represents coarse size; ratio $>1$ represents particles with size $<0.45 \mu \mathrm{m}$ and/or elements in solution.

Figure 6 shows that concentration of the snow of December 2009 is more enriched in cations compared to the last of March 2010.

The concentration of Na found at all sampling sites was due to the fact that sodium chloride had been used as de-icing agent on the roads [116].

Some samples show high concentrations of metals represented by the low ratio for the elements Iron and Aluminum, which tend to form insoluble hydroxides. Iron is represented by a ratio filtrate/suspended $\leq 1$, in almost samples, especially in the snow of December 2009 and February 2010. In the snow of March 2010 the ratio filtrate/suspended is major than 1 (samples C2 and C4, Figure 6(c)), probably due to the presence of bivalent Iron partially soluble. The Aluminum concentration showed the same trend of the Iron. The Aluminum ratio filtrate/suspended is major than 1 in some samples collected distant main road (sample A2 of December 2009 Figure 6(a), sample B6 in February 2010 - Figure 6(b); samples C2, C3 and C6 in March 2010 - Figure 6(c)). In general, the Aluminum is the element that changes more, in some samples is in solution but not in other. It is important to better understand the behavior of Aluminum, to know if it could be a pollutant that could create damage to groundwater. Ferrara is an area where the aquifer recharge is given by the rains, if the snow is polluted, when it melts and recharges aquifers, pollutes the water.

The high concentration of Zinc in some samples confirms the anthropogenic pollution, especially in the sample A1 of December 2009, which was collected near a main road. From literature, Zinc enrichment in the solid and liquid formations is an indicator of pollution [117].

Some researchers have founded that the correlation between suspended solid and chemical element decrease with the increase of the particle size [6] [118] [119].

Our results of heavy metal concentrations are in agreement with those reported by [2] [116] [120]. They have found that heavy metals concentration of $\mathrm{Pb}, \mathrm{Cu}, \mathrm{Cd}, \mathrm{Zn}, \mathrm{Al}, \mathrm{Mg}$ and $\mathrm{Fe}$ increase with the increase of the particle size, especially in snow samples exposed to urban traffic.

Figure 6 shows the correlation found between the concentration of elements mainly originating from anthropogenic sources (Fe, $\mathrm{Zn}$ and $\mathrm{Al}$ ) and the fine particles, especially in the snowfall of December and February.

Table 1 shows the total ratio between filtered and suspended of the samples collected in Ferrara in the three snow events, to know the anthropogenic contribution from vehicular traffic. The samples collected in Codigoro not appear, because they weren't collected in December.

Samples 1 and 2 were collected near main street and were more polluted than samples 3 and 4 . In these two samples ( 3 and 4 ) the ratio was major than 1 in all the snow events. This indicates a lower contribution from vehicular traffic.

Figure 7 shows metal concentration in snow samples at different locations analysed by ICP-MS. The data are obtained by averaging the results of sampling in December, February and March. Some of the elements are below the detection limit: $\mathrm{Fe}$ at one location (6) and $\mathrm{Pb}$ at one location (5), instead of $\mathrm{Ca}, \mathrm{Na}, \mathrm{K}$, and $\mathrm{Cu}$ have very low concentrations, near the detection limit (Ca and $\mathrm{Na}$ in the samples 2, 4, 5, 6; $\mathrm{K}$ in the samples 2 and 6; $\mathrm{Cu}$ in the samples 6). The highest concentration of $\mathrm{Na}$ in the sample 1 confirmed the fact that sodium chloride had been used as de-icing agent on the road. It is important to remember that sample 1 was collected near the main road of the sampling area [6].

Table 1. Total ratio between the filtered snow solution and the original snow solution of the samples collected in Ferrara analysed by ICP-MS.

\begin{tabular}{cccc}
\hline \multirow{2}{*}{ Sample } & December & February & March \\
\cline { 2 - 4 } & filt/susp & filt/susp & filt/susp \\
\hline $\mathbf{1}$ & 0.84 & 0.50 & 0.93 \\
$\mathbf{2}$ & 0.58 & 0.30 & 0.90 \\
$\mathbf{3}$ & 1.08 & 2.19 & 2.16 \\
$\mathbf{4}$ & 3.74 & 2.07 & 1.60 \\
\hline
\end{tabular}



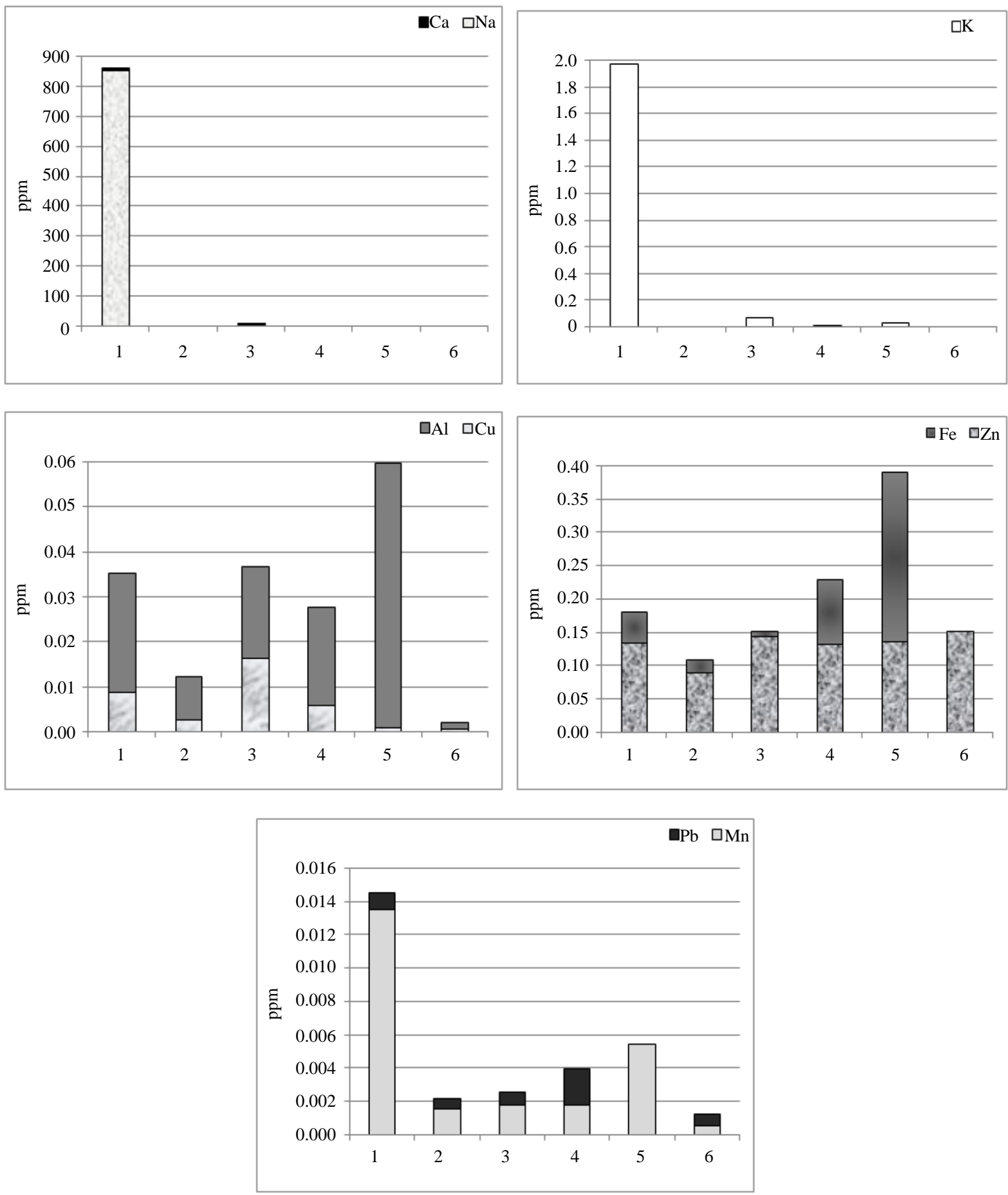

Figure 7. Metal concentration in snow samples at different locations analysed by ICP-MS.

The concentrations of $\mathrm{Ca}$ is probably due to contribution from mineral particles comprising carbonate (as in Figure 4(e) analysed by SEM-EDS). The higher concentration of $\mathrm{Ca}$ in the samples 1 (near the main road) confirms the use of de-icing agent on road. It is know that Ca is an impurity of de-icing salt [116].

$\mathrm{Mn}$ is higher in the samples collected near the main road (1 and 5). This is probably due to the fact that Mn has benne used as an additive to enhance vehicle performance [121].

$\mathrm{Al}, \mathrm{Cu}, \mathrm{Fe}, \mathrm{Ni}, \mathrm{Mn}$ and $\mathrm{Pb}$ represent pollution from anthropogenic activity. 


\section{Correlations}

Correlation analysis was performed to estimate the relationship between selected metals ( $\mathrm{Al}, \mathrm{Fe}, \mathrm{V}, \mathrm{Mn}, \mathrm{Cu}, \mathrm{Zn}$, $\mathrm{Se}, \mathrm{Te}, \mathrm{Pb}, \mathrm{Ba}, \mathrm{Sr}, \mathrm{Ca}, \mathrm{Mg}, \mathrm{K}$ ) against each other. Table 2 show the correlation coefficients calculated for filtered solution in the three different snowfall (A = December 2009; B = February 2010; $C=$ March 2010). Instead of Table 3 show the correlation coefficients calculated for suspended solution in the three different snowfall (A = December 2009; B = February 2010; C = March 2010).

Table 2. Correlation coefficient for the measured parameters for suspended solution in December 2009, February 2010, March 2010.

\begin{tabular}{|c|c|c|c|c|c|c|c|c|c|c|c|c|c|c|c|}
\hline & & $\mathrm{Fe}$ & V & Mn & $\mathrm{Cu}$ & $\mathbf{Z n}$ & Se & Te & $\mathbf{P b}$ & Ba & Sr & Ca & Mg & $\mathbf{K}$ & $\mathrm{Na}$ \\
\hline \multirow{14}{*}{ 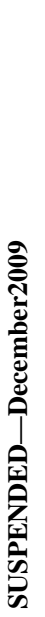 } & Al & 0.412 & 0.378 & 0.581 & 0.947 & -0.426 & n.d. & n.d. & 0.644 & 0.491 & 0.588 & 0.0 .569 & 0.581 & 0.591 & 0.576 \\
\hline & $\mathrm{Fe}$ & & 0.978 & 0.981 & .0413 & -0.999 & n.d. & n.d. & 1.000 & 1.000 & 0.984 & 0.986 & 0.984 & 0.983 & .0986 \\
\hline & $\mathbf{V}$ & & & 0.960 & 0.506 & -0.940 & n.d. & n.d. & 0.922 & 0.945 & 0.954 & 0.959 & 0.956 & 0.954 & 0.956 \\
\hline & Mn & & & & 0.636 & -0.971 & n.d. & n.d. & 0.992 & 0.986 & 1.000 & 1.000 & 1.000 & 1.000 & 1.000 \\
\hline & $\mathrm{Cu}$ & & & & & -0.446 & n.d. & n.d. & 0.661 & 0.515 & 0.636 & 0.619 & 0.631 & 0.639 & 0.623 \\
\hline & $\mathrm{Zn}$ & & & & & & n.d. & n.d. & -0.958 & -0.997 & -0.972 & -0.977 & -0.974 & -0.971 & -0.976 \\
\hline & Se & & & & & & & n.d. & n.d. & n.d. & n.d. & n.d. & n.d. & n.d. & n.d. \\
\hline & Te & & & & & & & & n.d. & n.d. & n.d. & n.d. & n.d. & n.d. & n.d. \\
\hline & $\mathbf{P b}$ & & & & & & & & & 0.975 & 0.993 & 0.990 & 0.992 & 0.994 & 0.991 \\
\hline & Ba & & & & & & & & & & 0.987 & 0.990 & 0.988 & 0.987 & 0.990 \\
\hline & $\mathrm{Sr}$ & & & & & & & & & & & 1.000 & 1.000 & 1.000 & 1.000 \\
\hline & Ca & & & & & & & & & & & & 1.000 & 1.000 & 1.000 \\
\hline & Mg & & & & & & & & & & & & & 1.000 & 1.000 \\
\hline & $\mathbf{K}$ & & & & & & & & & & & & & & 1.000 \\
\hline \multirow{20}{*}{ 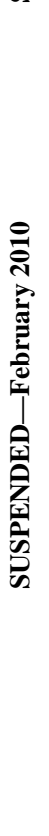 } & Al & 0.470 & 0.742 & 0.994 & -0.249 & -0.353 & n.d. & -0.282 & 1.000 & 0.957 & 0.967 & 0.986 & -0.998 & 0.990 & 0.780 \\
\hline & $\mathbf{F e}$ & & 0.940 & 0.575 & 0.165 & 0.913 & n.d. & -0.062 & n.d. & 0.707 & 0.537 & 0.376 & -0.519 & -1.000 & 0.401 \\
\hline & $\mathbf{V}$ & & & 0.357 & -0.505 & 0.609 & n.d. & 0.308 & 1.000 & 0.459 & 0.534 & 0.385 & -0.367 & 0.462 & 0.562 \\
\hline & Mn & & & & -0.142 & -0.319 & n.d. & -0.269 & 0.866 & 0.945 & 0.918 & 0.962 & -0.881 & 0.967 & 0.055 \\
\hline & $\mathrm{Cu}$ & & & & & -0.598 & n.d. & -0.818 & 0.772 & -0.504 & -0.454 & -0.397 & 0.678 & -0.181 & -0.504 \\
\hline & $\mathbf{Z n}$ & & & & & & n.d. & 0.928 & -0.594 & 0.590 & -0.028 & -0.170 & -0.615 & -0.302 & 0.184 \\
\hline & Se & & & & & & & n.d. & n.d. & n.d. & n.d. & n.d. & n.d. & n.d. & n.d. \\
\hline & Te & & & & & & & & -0.722 & 0.680 & 0.030 & -0.046 & -0.821 & -0.220 & 0.403 \\
\hline & $\mathbf{P b}$ & & & & & & & & & 1.000 & 0.922 & 0.710 & 1.000 & 0.986 & -0.954 \\
\hline & Ba & & & & & & & & & & 0.969 & 0.921 & -0.952 & 0.962 & 0.237 \\
\hline & Sr & & & & & & & & & & & 0.964 & -0.970 & 0.908 & 0.377 \\
\hline & $\mathrm{Ca}$ & & & & & & & & & & & & -0.926 & 0.928 & 0.183 \\
\hline & Mg & & & & & & & & & & & & & -0.806 & -0.392 \\
\hline & $\mathbf{K}$ & & & & & & & & & & & & & & -0.060 \\
\hline & Al & n.d. & n.d. & 0.077 & 0.972 & 0.559 & n.d. & -0.366 & -1.000 & n.d. & n.d. & -0.156 & 0.701 & n.d. & -0.139 \\
\hline & $\mathbf{F e}$ & & n.d. & n.d. & n.d. & n.d. & n.d. & n.d. & n.d. & n.d. & n.d. & n.d. & n.d. & n.d. & n.d. \\
\hline & $\mathbf{V}$ & & & n.d. & n.d. & n.d. & n.d. & n.d. & n.d. & n.d. & n.d. & n.d. & n.d. & n.d. & n.d. \\
\hline & Mn & & & & 0.832 & 0.026 & n.d. & 0.842 & n.d. & n.d. & n.d. & -0.392 & 0.858 & n.d. & 0.665 \\
\hline & $\mathbf{C u}$ & & & & & 0.593 & n.d. & -0.325 & n.d. & n.d. & n.d. & -0.699 & 0.720 & n.d. & 0.832 \\
\hline & $\mathbf{Z n}$ & & & & & & n.d. & -0.269 & -1.000 & n.d. & n.d. & -0.815 & -0.134 & n.d. & 0.034 \\
\hline \multirow{8}{*}{ 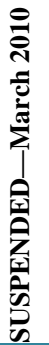 } & Se & & & & & & & n.d. & n.d. & n.d. & n.d. & n.d. & n.d. & n.d. & n.d. \\
\hline & Te & & & & & & & & 1.000 & n.d. & n.d. & -0.159 & 0.686 & n.d. & 0.676 \\
\hline & $\mathbf{P b}$ & & & & & & & & & n.d. & n.d. & 1.000 & 1.000 & n.d. & n.d. \\
\hline & Ba & & & & & & & & & & n.d. & n.d. & n.d. & n.d. & n.d. \\
\hline & Sr & & & & & & & & & & & n.d. & n.d. & n.d. & n.d. \\
\hline & $\mathrm{Ca}$ & & & & & & & & & & & & 0.318 & n.d. & -0.315 \\
\hline & Mg & & & & & & & & & & & & & n.d. & 0.858 \\
\hline & $\mathbf{K}$ & & & & & & & & & & & & & & n.d. \\
\hline
\end{tabular}


Table 3. Analysis results (mg/L) by ion chromatography of samples taken in the Ferrara and Codigoro in winter 2009/2010.

\begin{tabular}{|c|c|c|c|c|c|c|c|c|}
\hline Date & Location & Sample & $\mathrm{Fl}^{-}$ & $\mathrm{Cl}^{-}$ & $\mathrm{NO}_{2}^{-}$ & $\mathrm{Br}^{-}$ & $\mathrm{NO}_{3}^{-}$ & $\mathrm{SO}_{4}^{2-}$ \\
\hline $23 / 12 / 09$ & Fe: overpass front & A1 & 0.0109 & $\underline{6243.1}$ & n.d. & 1.0449 & 3.4993 & $\underline{113.41}$ \\
\hline $23 / 12 / 09$ & Fe: overpass back & A2 & 0.0360 & 1.3083 & n.d. & n.d. & 3.2622 & 1.9267 \\
\hline $23 / 12 / 09$ & Fe: parking & A3 & 0.0301 & $\underline{148.85}$ & n.d. & n.d. & 2.1404 & 4.2348 \\
\hline $23 / 12 / 09$ & Fe: garden & A4 & 0.0306 & 1.5692 & 0.0359 & n.d. & 4.1996 & 3.0752 \\
\hline $01 / 02 / 10$ & Fe: overpass front & B1 & 0.0148 & 3.8236 & n.d. & n.d. & 3.1449 & 0.4542 \\
\hline $01 / 02 / 10$ & Fe: overpass back & B2 & 0.0176 & 0.5308 & 0.0314 & n.d. & 3.1747 & 0.4762 \\
\hline $01 / 02 / 10$ & Fe: parking & B3 & 0.0363 & 0.9935 & 0.1131 & n.d. & 3.1403 & 0.7509 \\
\hline $01 / 02 / 10$ & Fe: garden & B4 & 0.0371 & 0.8268 & n.d. & n.d. & 6.3607 & 0.6445 \\
\hline $01 / 02 / 10$ & Codigoro: urban & B5 & 0.0269 & 2.0895 & 0.0112 & n.d. & 1.9847 & 0.7573 \\
\hline $01 / 02 / 10$ & Codigoro: suburban & B6 & 0.0007 & 1.3404 & n.d. & n.d. & 1.5169 & 0.4464 \\
\hline $10 / 03 / 10$ & Fe: overpass front & $\mathrm{C} 1$ & 0.0005 & 0.6059 & n.d. & n.d. & 0.5945 & 1.4595 \\
\hline $10 / 03 / 10$ & Fe: overpass back & $\mathrm{C} 2$ & 0.0008 & 0.7031 & n.d. & n.d. & 0.5728 & 1.6401 \\
\hline $10 / 03 / 10$ & Fe: parking & C3 & 0.0009 & 0.5535 & n.d. & n.d. & 0.6011 & 1.4232 \\
\hline $10 / 03 / 10$ & Fe: garden & $\mathrm{C} 4$ & 0.0002 & 0.5614 & n.d. & n.d. & 0.6220 & 1.5041 \\
\hline $10 / 03 / 10$ & Codigoro: urban & C5 & 0.0003 & 1.4129 & n.d. & n.d. & 0.2037 & 0.4763 \\
\hline $10 / 03 / 10$ & Codigoro: suburban & C6 & 0.0004 & 0.1865 & 0.0545 & n.d. & 0.2168 & 0.3710 \\
\hline
\end{tabular}

Table 2 shows a strange correlation between Na concentration and Zn concentration. In the snowfall of December the correlation was negative [6], instead of in the snowfall of February and March the correlation was positive [122].

The analysis showed a strong positive correlation between Na and Ca both for the snowfall of December $\left(\mathrm{R}^{2}\right.$ $=0.99$ ) and February, This suggest the same sources, and it is probably a consequences of the fact that salt used as a de-icing agent contain calcium impurities [6].

Table 2 shows a strange correlation between Na concentration and K concentration. In the snowfall of December the correlation was positive $\left(\mathrm{R}^{2}=0.99\right)$, instead of in the snowfall of February the correlation was negative. The salt used as a de-icing agent probably contains potassium as impurities [6].

Some metals from anthropogenic sources are strongly correlated. Positive correlations were found between Al and $\mathrm{Cu}$ in the snowfall of December $\left(\mathrm{R}^{2}=0.87\right)$ and March $\left(\mathrm{R}^{2}=0.94\right)$, instead of negative correlation in the snowfall of February. The opposite was for Fe and Zn, in the snowfall of December a negative correlation, instead of positive correlation in the snowfall of February $\left(\mathrm{R}^{2}=0.17\right)$.

A positive correlation was observed between $\mathrm{Ca}$ and $\mathrm{K}$, thus indicating that these elements originate from the same sources (December $\mathrm{R}^{2}=0.99$ and February $\mathrm{R}^{2}=0.85$ ). The same positive correlation was observed between $\mathrm{Ca}$ and $\mathrm{Pb}$.

\subsection{Chemical Composition by IC Technique}

In some samples, nitrates and bromides are under the detection limit (LOD), which represents the minimum concentration of analita detectable (Table 3). Phosphates under the detection limit. The symbol "n.d.” means "value comparable with white value”. The concentrations of the fluorides analyzed are low in all samples.

Table 3 shows that some elements (chloride, nitrates and sulfates) are relatively high, especially in the snowfall of December 2009. This can be explained by the sampling carried out two days after the snowfall. Probably the snow had already absorbed part of smog of the vehicular traffic. This high contribution can therefore be related to anthropogenic sources.

The high concentration of chlorides found at all sampling sites, especially near the main road in the snowfall 
of December, was due to the fact that sodium chloride had been used as de-icing agent on the roads (confirmed by the high concentration of sodium analyzed by ICP-MS).

The presence of nitrates and sulphates may indicate mineral acidity of the snow sample. These ions, in fact, are formed in the atmosphere by oxidation and subsequent reaction with water of the oxides of nitrogen (NOx) and sulfur dioxide $\left(\mathrm{SO}_{2}\right)$. The presence of nitrogen oxides into the atmosphere is mainly due to the presence of sulfuric and sulphurous anhydrides by the combustion of the gas turbine central and/or incinerators. In recent years, the sulfate ion has had a strong reduction in Western countries, in which people use sulfur-free petrol, while in countries without environmental legislation this ion continues to be injected. For this reason, the presence of the sulfate ion may be indicative of cross-border contributions $\left(\mathrm{SO}_{2}\right)$ formed during the combustion of coal and fuel oils.

In Ferrara city, the sulphates are brought down by reducing the amount of fuel with the introduction of geothermal energy and using gasoline without sulfur. The abnormal presence of sulphate ions could be an indicator of transboundary sources from foreign countries, where this is not adopted.

From the snowfall of December to March, the ion concentrations decrease, especially in the city of Ferrara:

- from $0.03 \mathrm{mg} / \mathrm{L}$ to $0.0006 \mathrm{mg} / \mathrm{L}$ for fluorides;

- from $3.3 \mathrm{mg} / \mathrm{L}$ to $0.6 \mathrm{mg} / \mathrm{L}$ for nitrates;

- from hundreds of $\mathrm{mg} / \mathrm{L}$ to $0.5 \mathrm{mg} / \mathrm{L}$ for chlorides;

- from hundreds of $\mathrm{mg} / \mathrm{L}$ to $1.5 \mathrm{mg} / \mathrm{L}$ for sulphates.

Even in Codigoro, the concentration decrease from February to March.

\section{Conclusions}

In this project, issues of sampling and analytical procedures related to snow samples with very low concentrations and subject to easy contamination have been addressed [73].

Sampling procedures were determined and the identification of the particulate matter in samples of snow was made by chemical methods (ICP-MS and IC) and observations by SEM-EDS.

SEM-EDS analysis of snow samples shows that the particles are single or agglomerate.

The major components of snow are the inorganic particles as shown by SEM-EDS measurements, which have allowed the identification of the morphology and chemical composition of the various types of particles, which are formed by silicates, allumo silicates, carbonates and organic particles.

From the ICP-MS analysis, the alkaline elements are concentrated in the fraction suspended and they are present as allumo silicates with dimensions larger than those of the filter $(>0.45 \mu \mathrm{m})$. This indicates a resuspension of local soil.

The presence of chloride, nitrate and sulphate is important and it is related with anthropogenic sources (smog of the vehicular traffic). Data were obtained from the analysis in IC.

The experimental results have allowed for a good response that the analysis of snow can give to estimate the transboundary contributions and possible anthropic impacts.

This study suggests that there is a direct contamination of snow in the Po Valley from the activity of vehicular traffic and therefore an important deposit of trace elements is close to the busiest streets.

The results suggest a method to use to continue the study of particulate matter in the snow, because it is particularly interesting to estimate the contribution of various pollution sources and to understand the risk factors for people and ecosystems in the sampling area. The snow melted, in fact, favors the interaction of the particles contained in it with biomass. Furthermore, the solid particles in the snow can then be resuspended and be inhaled by humans, with the melting of the snow.

\section{Acknowledgements}

We would like to thank Renzo Tassinari and Maria Rita Bovolenta for their precious help in analyzing samples by ICP-MS and SEM-EDS respectively.

\section{References}

[1] Barbante, C., Cozzi, G., Capodaglio, G., Van De Velde, K., Ferrari, C., Boutron, C. and Cescon, P. (1999) Trace Element Determination in Alpine Snow and Ice by Double Focusing Inductively Coupled Plasma Mass Spectrometry with Microconcentric Nebulization. Journal of Analytical Atomic Spectrometry, 14, 1433-1438. 
http://dx.doi.org/10.1039/a901949i

[2] Sansalone, J.J., Glenn, D.W. and Tribouillard, T. (2003) Physical and Chemical Characteristics of Urban Snow Residuals Generated from Traffic Activities. Water Air and Soil Pollution, 148, 45-60. http://dx.doi.org/10.1023/A:1025446612833

[3] Reinsdotter, K. and Viklander, M. (2005) A Comparison of Snow Quality in Two Swedish Municipalities: Lulea and Sundsvall. Water Air and Soil Pollution, 167, 3-16. http://dx.doi.org/10.1007/s11270-005-8635-3

[4] Bizotto, E.C., Villa, S., Vaj, C. and Vighi, M. (2009) Comparison of Glacial and Non-Glacial Fed Streams to Evaluate the Loading of Persistent Organic Pollutants through Seasonal Snow/Ice Melt. Chemosphere, 74, 924-930. http://dx.doi.org/10.1016/j.chemosphere.2008.10.013

[5] Bartles-Rausch, T., Krysztofiak, G., Bernhard, A., Schläppi, M., Schwikowski, M. and Ammann, M. (2011) Photoinduced Reduction of Divalent Mercury in the Ice by Organic Matter. Chemosphere, 82, 199-203. http://dx.doi.org/10.1016/j.chemosphere.2010.10.020

[6] Vasić, M.V., Mihailovic, A., Kozmidis-Luburić, U., Nemes, T., Ninkov, J., Zeremski-Skorić, T. and Antić, B. (2012) Metal Contamination of Short-Term Snow Cover near Urban Crossroads: Correlation Analysis of Metal Content and Fine Particles Distribution. Chemosphere, 85, 585-592. http://dx.doi.org/10.1016/j.chemosphere.2011.10.023

[7] Decreto Ministeriale 2 aprile 2002, No. 60. Recepimento della Direttiva 1999/30/CE del consiglio del 22 aprile 1999. Documento 402H0060.000 di Origine Nazionale, emanato da: Ministro dell'Ambiente e della Tutela del Territorio e pubblicato sulla Gazzetta Ufficiale Supplemento Ordin. No. 87 del 13/04/2002.

[8] Direttiva 1999/30/CE del Consiglio del 22 aprile 1999. Concernente i valori limite di qualità dell'aria ambiente per il biossido di zolfo, il biossido di azoto, gli ossidi di azoto, le particelle e il piombo. Pubblicatosu: Gazzettaufficiale n. L 163 del 29/06/1999, 0041-0060.

[9] Polichetti, G., Cocco, S., Spinali, A., Trimarco, V. and Nunziata, A. (2009) Effects of Particulate Matter $\left(\mathrm{PM}_{10}, \mathrm{PM}_{2.5}\right.$ and $\mathrm{PM}_{1}$ ) on the Cardiovascular System. Toxicology, 261, 1-8. http://dx.doi.org/10.1016/j.tox.2009.04.035

[10] Scapellato, M.L., Canova, C., Simone, A., Carrieri, M., Maestrelli, P., Simonato, L. and Bartolucci, G.B. (2009) Personal $\mathrm{PM}_{10}$ Exposure in Asthmatic Adults in Padova, Italy: Seasonal Variability and Factors Affecting Individual Concentrations of Particulate Matter. International Journal of Hygiene and Environmental Health, 212, 626-636. http://dx.doi.org/10.1016/j.ijheh.2009.06.001

[11] Metallo, M.C., Poli, A.A., Diana, M., Persia, F. and Cirillo, M.C. (1995) Air Pollution Loads on Historical Monuments: An Air Quality Model Application to the Marble Arch of Titus in Rome. Science of the Total Environment, 171, 163172. http://dx.doi.org/10.1016/0048-9697(95)04690-0

[12] Primerano, P., Marino, G., Di Pasquale, S., Mavilia, L. and Corigliano, F. (2000) Possible Alteration of Monuments Caused by Particles Emitted into the Atmosphere Carrying Strong Primary Acidity. Atmospheric Environment, 34, 3889-3896. http://dx.doi.org/10.1016/S1352-2310(00)00183-7

[13] Kampa, M. and Castanas, E. (2008) Human Health Effects of Air Pollution. Environmental Pollution, 151, $362-367$. http://dx.doi.org/10.1016/j.envpol.2007.06.012

[14] Kim, H.W., Ahn, E.K., Jee, B.K., Yoon, H.K., Lee, K.H. and Lim, Y. (2009) Nanoparticulate-Induced Toxicity and Related Mechanism in Vitro and in Vivo. Journal of Nanoparticle Research, 11, 55-65. http://dx.doi.org/10.1007/s11051-008-9447-3

[15] Huang, J., Kang, S., Zhang, Q., Guo, J., Chen, P., Zhang, G. and Tripathee, L. (2013) Atmospheric Deposition of Trace Elements Recorded in Snow from the Mt. Nyainqêntanglha Region, Southern Tibetan Plateau. Chemosphere, 92, 871881. http://dx.doi.org/10.1016/j.chemosphere.2013.02.038

[16] Pacyna, J.M. and Pacyna, E.G. (2001) An Assessment of Global and Regional Emissions of Trace Metals to the Atmosphere from Anthropogenic Sources Worldwide. Environmental Research, 9, 269-298.

[17] Sposito, G. (2008) The Chemistry of Soils. Second Edition, Oxford University Press Inc., New York.

[18] Shridhar, V., Khillare, P.S., Agarwal, T. and Ray, S. (2010) Metallic Species in Ambient Particulate Matter at Rural and Urban Location of Delhi. Journal of Hazardous Materials, 175, 600-607.

http://dx.doi.org/10.1016/j.jhazmat.2009.10.047

[19] Goldschmidt, V.M. (1954) Geochemistry. Clarendon Press, Oxford.

[20] Schumacher, M., Bocio, A., Agramunt, M.C., Domingo, J.L. and De Kok, H.A.M. (2002) PCDD/F and Metal Concentrations in Soil and Herbage Samples Collected in the Vicinity of a Cement Plant. Chemosphere, 48, 209-217. http://dx.doi.org/10.1016/S0045-6535(02)00042-5

[21] Querol, X., Viana, M., Alastuey, A., Amato, F., Moreno, T. and Catillo, S. (2007) Source Origin of Trace Elements in PM from Regional Background, Urban and Industrial Sites of Spain. Atmospheric Environment, 41, 7219-7231.

[22] Santacatalina, M., Reche, C., Minguillón, M.C., Escrig, A., Sanfelix, V., Carratalà, A., Nicolàs, J.F., Yubero, E., Cres- 
po, J., Alaustery, A., Monfort, E., Mirò, J.V. and Querol, X. (2010) Impact of Fugitive Emissions in Ambient PM Levels and Composition. A Case Study in Southeast Spain. Science of the Total Environment, 408, 4999-5009.

http://dx.doi.org/10.1016/j.scitotenv.2010.07.040

[23] Chen, Y.Z., Shah, N., Huggins, F.E., Huffman, G.P., Linak, W.P. and Miller, C.A. (2004) Investigation of Primary Fine Particulate Matter from Coal Combustion by Computer-Controlled Scanning Electron Microscopy. Fuel Processing Technology, 85, 743-761. http://dx.doi.org/10.1016/j.fuproc.2003.11.017

[24] Maenhaut, W., Francois, F., Cafmeyer, J. and Okunade, O. (1996) Size-Fractionated Aerosol Composition at Gent, Belgium. Results from a One-Year Study. Nuclear Instruments and Methods in Physics Research Section B, 109, 476781. http://dx.doi.org/10.1016/0168-583X(95)00954-X

[25] Lienemann, C.P., Dreyfus, S., Pecheyran, C. and Donard, O.F.X. (2007) Trace Metal Analysis in Petroleum Products: Sample Introduction Evaluation in ICP-OES and Comparison with an ICP-MS Approach. Oil \& Gas Science and Technology, 62, 69-77. http://dx.doi.org/10.2516/ogst:2007006

[26] Mason, B. (1996) Principles of Geochemistry. Third Edition, John Wiley \& Sons, Inc., Hoboken.

[27] Fang, G., Wu, Y., Huang, S. and Rau, J. (2005) Review of Atmospheric Metallic Elements in Asia during 2000-2004. Atmospheric Environment, 39, 3003-3013. http://dx.doi.org/10.1016/j.atmosenv.2005.01.042

[28] Fang, G., Wu, Y., Wen, C., Huang, S. and Rau, J. (2006) Ambient Air Particulate Concentrations and Metallic Elements Principal Component Analysis at Taichung Harbor (TH) and WuChi Traffic (WT) near Taiwan Strait during 2004-2005. Journal of Hazardous Materials, 137, 314-323. http://dx.doi.org/10.1016/j.jhazmat.2006.02.017

[29] Thomas, S. and Morawska, L. (2002) Size-Selected Particles in an Urban Atmosphere of Brisbane, Australia. Atmospheric Environment, 36, 4277-4288. http://dx.doi.org/10.1016/S1352-2310(02)00345-X

[30] Mackey, J.R., Watt, S.T., Cardy, C.A., Smith, S.I. and Meunier, C.A. (1991) Analysis of Additive Metals in Lubricating Oils. In: Nadkarni, R.A., Ed., Modem Instrumental Methods of Elemental Analysis of Petroleum Products and Lubricants. ASTM STP 1109. American Society for Testing and Materials, Philadelphia, 52-61. http://dx.doi.org/10.1520/STP14551S

[31] Mateu, J., Forteza, R., Cerda, V. and Colomaltes, M. (1995) Comparison of Various Methods for the Determination of Inorganic Species in Airborne Atmospheric Particulates. Water Air and Soil Pollution, 84, 61-79. http://dx.doi.org/10.1007/BF00479589

[32] Kumar, A.V., Patil, R.S. and Nambi, K.S.V. (2001) Source Apportionment of Suspended Particulate Matter at Two Traffic Junctions in Mumbai, India. Atmospheric Environment, 35, 4245-4251. http://dx.doi.org/10.1016/S1352-2310(01)00258-8

[33] Napier, F., D’Arcy, B. and Jefferies, C. (2008) A Review of Vehicle Related Metals and Polycyclic Aromatic Hydrocarbons in the UK Environment. Desalination, 226, 143-150. http://dx.doi.org/10.1016/j.desal.2007.02.104

[34] Tandon, A., Yadav, S. and Attri, A.K. (2008) City-Wide Sweeping a Source for Respirable Particulate Matter in the Atmosphere. Atmospheric Environment, 42, 1064-1069. http://dx.doi.org/10.1016/j.atmosenv.2007.12.006

[35] Thorpe, A. and Harrison, R.M. (2008) Sources and Properties of Non-Exhaust Particulate Matter from Road Traffic: A Review. Science of the Total Environment, 400, 270-282. http://dx.doi.org/10.1016/j.scitotenv.2008.06.007

[36] Davidson, C.J. and Pacyna, J.M. (1986) Emission Factors of Atmospheric Elements. In: Nriagu, J.O. and Davidson, C.I., Eds., Toxic Metals in the Atmosphere, John Wiley and Sons, Inc., New York, 355-390.

[37] Ruth, O. (2003) The Effects of De-Icing in Helsinki Urban Streams, Southern Finland. Water Science and Technology, 48, 33-43.

[38] Blais, J.M., Schindler, D.W., Muir, D.C.G., Sharp, M., Donald, D., Lafrenière, M., Braekevelt, E. and Strachan, W.M.J. (2001) Melting Glaciers Are a Dominant Source of Persistent Organochlorines to Subalpine Bow Lake in Banff National Park, Canada. Ambio, 30, 410-415.

[39] Peters, A.J., Gregor, D.J., Teixeira, C.F., Jones, N.P. and Spencer, C. (1995) The Recent Depositional Trend of Polycyclic Aromatic Hydrocarbons and Elemental Carbon to the Agassiz Ice Cap, Ellesmere Island, Canada. Science of the Total Environment, 160-161, 167-179. http://dx.doi.org/10.1016/0048-9697(95)04354-4

[40] Donald, D.B., Syrgiannia, J., Crosley, R.W., Holdsworth, G., Muir, D.C.G., Rosenberg, B., Sole, A. and Schindler, D.W. (1999) Delayed Deposition of Organochlorine Pesticides at a Temperate Glacier. Environmental Science and Technology, 33, 1794-1798. http://dx.doi.org/10.1021/es981120y

[41] Hong, S., Candelone, J.P., Patterson, C.C. and Bouton, C.F. (1994) Greenland Ice Evidence of Hemispheric Lead Pollution Two Millennia Ago by Greek and Roman Civilization. Science, 265, 1841-1843. http://dx.doi.org/10.1126/science.265.5180.1841

[42] Barbante, C., Veysseyre, A., Ferrari, C.P., Van De Velde, K., Morel, C., Capodaglio, G., Cescon, P., Scarponi, G. and Bouton, C. (2001) Greenland Snow Evidence of Large Scale Atmospheric Contamination for Platinum, Palladium and 
Rhodium. Environmental Science and Technology, 35, 835-839. http://dx.doi.org/10.1021/es000146y

[43] Barbante, C., Bouton, C., Morel, C., Ferrari, C.P., Jaffrezo, J.I., Cozzi, G., Gaspari, V. and Cescon, P. (2003) Seasonal Variations of Heavy Metals in Central Greenland Snow Deposited from 1991 to 1995. Journal of Environmental Monitoring, 5, 328-335. http://dx.doi.org/10.1039/b210460a

[44] McConnel, J.R. and Edwards, R. (2008) Coal Burning Leaves Toxic Heavy Metal Legacy in the Arctic. Proceedings of the National Academy of Sciences of the United States of America, 105, 12140-12144. http://dx.doi.org/10.1073/pnas.0803564105

[45] Shotyk, W., Zheng, J., Krachler, M., Zdanowicz, C., Koerner, R.M. and Fischer, D. (2005) Predominance of Industrial $\mathrm{Pb}$ in Recent Snow (1994-2004) and Ice (1842-1996) from Devon Island, Arctic Canada. Geophysical Research Letters, 32, Article ID: L21814. http://dx.doi.org/10.1029/2005GL023860

[46] Zheng, J., Shotyk, W., Krachler, M. and Fisher, D.A. (2007) A 15,800-Year Record of Atmospheric Lead Deposition on the Devon Island Ice Cap. Nunavut, Canada: Natural and Anthropogenic Enrichments, Isotopic Composition and Predominant Sources. Global Biogeochemical Cycles, 21, GB2027. http://dx.doi.org/10.1029/2006GB002897

[47] Krachler, M., Zheng, J., Fisher, D. and Shotyk, W. (2008) Atmospheric Inputs of Ag and Tl to the Arctic: Comparison of a High Resolution Snow Pit (AD 1994-2004) with a Firn (AD 1860-1996) and an Ice Core (Previous 16,000 yr). Science of the Total Environment, 399, 78-89. http://dx.doi.org/10.1016/j.scitotenv.2008.03.006

[48] Planchon, F.A.M., Boutron, C.F., Barbante, C., Cozzi, G., Gaspari, V., Wolff, E.W., Ferrari, C.P. and Cescon, P. (2002) Changes in Heavy Metals in Antarctic Snow from Coats Land since the Mid-19th to the Late-20th Century. Earth and Planetary Science Letters, 200, 207-222. http://dx.doi.org/10.1016/S0012-821X(02)00612-X

[49] Gabrielli, P., Barbante, C., Boutron, C.F., Cozzi, G., Gaspari, V., Planchon, F., Ferrari, C. and Cescon, P. (2005) Variations in Atmosphere Trace Elements in Dome C (East Antarctica) Ice over the Last Two Climatic Cycles. Atmospheric Environment, 39, 6420-6429.

[50] Hur, S.D., Cunde, X., Hong, S., Barbante, C., Gabrielli, P., Lee, K., Boutron, C.F. and Ming, Y. (2007) Seasonal Patterns of Heavy Metal Deposition to the Snow on Lambert Glacier Basin, East Antarctica. Atmospheric Environment, 41, 8567-8578. http://dx.doi.org/10.1016/j.atmosenv.2007.07.012

[51] Jitaru, P., Gabrielli, P., Marteel, A., Plane, J.M.C., Planchon, F.A.M., Gauchard, P.A., Ferrari, C.P., Boutron, C.F., Adams, F.C. and Hong, S. (2009) Atmospheric Depletion of Mercury over Antarctica during Glacier Periods. Nature Geoscience, 2, 505-508. http://dx.doi.org/10.1038/ngeo549

[52] Li, Z.Q., Li, C.J., Li, Y.F., Wang, F.T. and Li, H.I. (2007) Preliminary Results from Measurements of Selected Trace Metals in the Snowfirn Pack on Urumqi Glacier No. 1, Eastern Tien Shan, China. Journal of Glaciology, 53, 368-373.

[53] Liu, Y., Hou, S., Hong, S., Do Hur, S., Lee, K. and Wang, Y. (2011) High-Resolution Trace Element Records of an Ice Core from the Eastern Tien Shan, Central Asia, since 1953 AD. Journal of Geophysical Research, 116, Article ID: D12307.

[54] Li, Y., Yao, T., Wang, N., Li, Z., Tian, I., Xu, B. and Wu, G. (2006) Recent Changes of Atmospheric Heavy Metals in a High-Elevation Ice Core from Muztagh Ata, East Pamirs: Initial Results. Annals of Glaciology, 43, 154-159.

[55] Li, Z., Yao, T., Tian, I., Xu, B. and Li, Y. (2006) Atmospheric Pb Variations in Central Asia since 1955 from Muztagata Ice Core Record, Eastern Pamirs. Chinese Science Bulletin, 51, 1996-2000.

[56] Aizen, V.B., Mayewski, P.A., Aizen, E.M., Joswiak, D.R., Surazakov, A.B., Kaspari, S., Grigholm, B., Krachler, M., Handley, M. and Finaev, A. (2009) Stable-Isotope and Trace Element Time Series from Fedchenko Glacier (Pamirs) Snow/Firn Cores. Journal of Glaciology, 55, 275-291. http://dx.doi.org/10.3189/002214309788608787

[57] Kang, S., Zhang, Q., Kaspari, S., Qin, D., Cong, Z., Ren, J. and Mayewski, P.A. (2007) Spatial and Seasonal Variations of Elemental Composition in Mt. Everest (Qomolangma) Snow/Firn. Atmospheric Environment, 41, $7208-7218$. http://dx.doi.org/10.1016/j.atmosenv.2007.05.024

[58] Duan, J., Ren, J., Qin, X. and Li, Y. (2007) Heavy Metal Concentrations and Seasonal Variations in Snow of Mount Everest Region. Acta Geographica Sinica, 62, 22-29.

[59] Lee, K., Hur, D.S., Hou, S., Hong, S., Qin, X., Ren, J., Liu, Y., Rosman, K.J.R., Barbante, C. and Boutron, C.F. (2008) Atmospheric Pollution for Trace Elements in the Remote High-Altitude Atmosphere in Central Asia as Record in Snow from Mt. Qomolangma (Everest) of the Himalayas. Science of the Total Environment, 404, 171-181. http://dx.doi.org/10.1016/j.scitotenv.2008.06.022

[60] Jickells, T.D., Davies, T.D., Tranter, M., Landsberger, S., Jarvis, K. and Abrahams, P. (1992) Trace Elements in Snow Samples from the Scottish Highlands: Sources and Dissolved/Particulate Distributions. Atmospheric Environment, 26, 393-401. http://dx.doi.org/10.1016/0960-1686(92)90325-F

[61] Kay, J.E., Gillespie, A.R., Hansen, G.B. and Pettit, E.C. (2003) Spatial Relationship between Snow Contaminant Content, Grain Size and Surface Temperature from Multispectral Images of Mt. Rainier, Washington, (USA). Remote Sensing of Environment, 86, 216-231. http://dx.doi.org/10.1016/S0034-4257(03)00102-0 
[62] Van De Velde, K., Ferrari, C.P., Barbante, C., Moret, I., Bellomi, T., Hong, S. and Boutron, C. (1999) A 200 Year Record of Atmospheric Cobalt, Chromium, Molybdenum and Antimony in High Altitude Alpine Firn and Ice. Environmental Science and Technology, 33, 3495-3501.

[63] Van De Velde, K., Barbante, C., Cozzi, G., Moret, I., Bellomi, T., Ferrari, C.P. and Boutron, C. (2000) Changes in the Occurrence of Silver, Gold, Platinum, Palladium and Rhodium in Mont Blanc Ice and Snow since the 18th Century. Atmospheric Environment, 34, 3117-3127.

[64] Van de Velde, K., Boutron, C.F., Ferrari, C.P., Moreau, A.L., Delmas, R.J., Barbante, C., Bellomi, T. and Capodoglio, G. (2000) A Two Hundred Years Record of Atmospheric Cadmium, Copper and Zinc Concentrations in High Altitude Snow and Ice from the French-Italian Alps. Geophysical Research Letters, 27, 249-252.

[65] Rosman, K.J.R., Ly, C., Van de Velde, K. and Boutron, C.F. (2000) A Two Century Record of Lead Isotopes in High Altitude Alpine Snow and Ice. Earth and Planetary Science Letters, 176, 413-424.

[66] Barbante, C., Van de Velde, K., Cozzi, G., Capodoglio, G., Cescon, P., Planchon, F., Hong, S., Ferrari, C.P. and Boutron, C.F. (2001) Post-World War II Uranium Changes in Dated Mont Blanc Ice and Snow. Environmental Science and Technology, 35, 4026-4030.

[67] Barbante, C., Boutron, C.F., Moreau, A.L., Ferrari, C.P., Van de Velde, K., Cozzi, G., Turetta, C. and Cescon, P. (2002) Seasonal Variations in Nickel and Vanadium in Mont Blanc Snow and Ice Dated from the 1960s and 1990s. Journal of Environment Monitoring, 4, 960-966. http://dx.doi.org/10.1039/b208142c

[68] Barbante, C., Schwikowski, M., Döring, T., Gäggeler, H.W., Schotterer, U., Tobler, L., Van De Velde, K., Ferrari, C.P., Cozzi, G. and Turetta, A. (2004) Historical Record of European Emissions of Heavy Metals to the Atmosphere since the 1650s from Alpine Snow/Ice Cores Drilled near Mont Rosa. Environmental Science and Technology, 38, 40854090. http://dx.doi.org/10.1021/es049759r

[69] Herbert, B.M.J., Halsall, C.J., Fitzpatrick, L., Villa, S., Jones, K.C. and Thomas, G.O. (2004) Use and Validation of Novel Snow Samplers for Hydrophobic, Semi-Volatile Organic Compounds (SVOCs). Chemosphere, 56, 227-235. http://dx.doi.org/10.1016/j.chemosphere.2004.03.004

[70] Hong, S., Barbante, C., Boutron, C.F., Gabrielli, P., Gaspari, V., Cescon, P., Thomson, D.S., Ferrarai, C.P., Francou, B. and Bourgoin, M. (2004) Atmospheric Heavy Metals in Tropical Sputh America during the Past 22,000 Years Recorded in a High Altitude Ice Core from Sajama, Bolivia. Journal of Environment Monitoring, 6, 222-226.

[71] Schwikowski, M., Barbante, C., Doering, T., Gaeggeler, H.W., Boutron, C., Schotterer, U., Tobler, I., Van De Velde, K., Ferrari, C. and Cozzi, G. (2004) Post-17th-Century Changes of European Lead Emissions Recorded in High-Altitude Alpine Snow and Ice. Environmental Science and Technology, 38, 957-964. http://dx.doi.org/10.1021/es034715o

[72] Gabrielli, P., Cozzi, G., Torcini, S., Cescon, P. and Barbante, C. (2008) Trace Elements in Winter Snow of the Dolomites (Italy): A Statistical Study of Natural and Anthropogenic Contributions. Chemosphere, 72, 1504-1509. http://dx.doi.org/10.1016/j.chemosphere.2008.04.076

[73] Telloli, C., Fazzini, M., Tassinari, R., Marrocchino, E. and Vaccaro, C. (2013) Monitoring of Solid Particulate Airborne Samples from Mountain Snow in Some Sites of the Alps, Italy. International Journal of Geosciences, 4, 711-723. http://dx.doi.org/10.4236/ijg.2013.44066

[74] Zinger, I. and Delisle, C.F. (1988) Quality of Used-Snow Discharged in the ST-Lawrence River, in the Region of the Montreal Harbor. Water Air and Soil Pollution, 39, 47-57. http://dx.doi.org/10.1007/BF00250947

[75] Boom, A. and Marsalek, J. (1988) Accumulation of Polycyclic Aromatic Hydrocarbons (PAHs) in an Urban Snowpack. Science of the Total Environment, 74, 133-148.

[76] Viklander, M. (1996) Urban Snow Deposits_-Pathways of Pollutants. Science of the Total Environment, 189-190, 379384. http://dx.doi.org/10.1016/0048-9697(96)05234-5

[77] Viklander, M. (1999) Substances in Urban Snow. A Comparison of the Contamination of Snow in Different Parts of the City of Lulea, Sweden. Water Air and Soil Pollution, 114, 377-394. http://dx.doi.org/10.1023/A:1005121116829

[78] Engelhard, C., De Toffol, S., Lek, I., Rauch, W. and Dallinger, R. (2007) Environmental Impacts of Urban Snow Management-The Alpine Case Study of Innsbruck. Science of the Total Environment, 382, 286-294. http://dx.doi.org/10.1016/j.scitotenv.2007.04.008

[79] Bućko, M.S., Magiera, T., Johanson, B., Petrovský, E. and Pesonen, L.J. (2011) Identification of Magnetic Particulates in Road Dust Accumulated on Roadside Snow Using Magnetic, Geochemical and Micro-Morphological Analyses. Environmental Pollution, 159, 1266-1276. http://dx.doi.org/10.1016/j.envpol.2011.01.030

[80] Viskari, E.L., Rekilä, R., Roy, S., Lehto, O., Ruuskanen, J. and Kärenlampi, L. (1997) Airborne Pollutants along a Roadside: Assessment Using Snow Analyses and Moss Bags. Environmental Pollution, 97, 153-160. http://dx.doi.org/10.1016/S0269-7491(97)00061-4 
[81] Hautala, E.L., Rekilä, R., Tarhanen, J. and Ruuskanen, J. (1995) Deposition of Motor Vehicle Emissions and Winter Maintenance along Roadside Assessed by Snow Analyses. Environmental Pollution, 87, 45-49. http://dx.doi.org/10.1016/S0269-7491(99)80006-2

[82] Atteia, O. (1994) Major and Trace Elements in Precipitation on Western Switzerland. Atmospheric Environment, 28, 3617-3624. http://dx.doi.org/10.1016/1352-2310(94)00193-O

[83] Poissant, L., Schmidt, J.P. and Béron, P. (1994) Trace Inorganic Elements in Rainfall in the Montreal Island. Atmospheric Environment, 28, 339-346. http://dx.doi.org/10.1016/1352-2310(94)90109-0

[84] Poissant, L., Koprivnjak, J.F. and Matthieu, R. (1997) Some Persistent Organic Pollutants and Heavy Metals in the Atmosphere over a St Lawrence River Valley Site (Villeroy) in 1992. Chemosphere, 34, 567-585. http://dx.doi.org/10.1016/S0045-6535(96)00353-0

[85] Riemann, C., Niskavaara, H., De Caritat, P., Finne, T.E., Ayras, M. and Chebuskin, V. (1996) Regional Variations of Snowpack Chemistry in the Vicinity of Nickel and Zapoljarnij, Russia, Northern Finland and Norway. The Science of the Total Environment, 182, 147-158. http://dx.doi.org/10.1016/0048-9697(95)05061-2

[86] Gregurek, D., Melcher, F., Niskavaara, H., Pavlov, V.A., Reimann, C. and Stumpfl, E.F. (1999) Platinum-Group Elements (Rh, Pt, Pb) and Au Distribution in Snow Samples from the Kola Peninsula, NW Russia. Atmospheric Environment, 33, 3281-3290. http://dx.doi.org/10.1016/S1352-2310(98)00434-8

[87] Simonetti, A., Gariepy, C. and Carignan, J. (2000) Pb and Sr Isotopic Compositions of Snowpack from Québec, Canada: Inferences on the Sources and Deposition Budgets of Atmospheric Heavy Metals. Geochimica and Cosmochimica Acta, 64, 5-20. http://dx.doi.org/10.1016/S0016-7037(99)00207-0

[88] Veysseyre, A., Moutard, K., Ferrari, C., Van de Velde, K., Barbante, C., Cozzi, G., Capodaglio, G. and Boutron, C. Heavy Metals in Fresh Snow Collected at Different Altitudes in Chamonix and Maurienne Valleys, French Alps: Initial Results. Atmospheric Environment, 35, 415-425. http://dx.doi.org/10.1016/S1352-2310(00)00125-4

[89] Westerlund, C. and Viklander, M. (2006) Particles and Associated Metals in Road Runoff during Snowmelt and Rainfall. Science of the Total Environment, 362, 143-156. http://dx.doi.org/10.1016/j.scitotenv.2005.06.031

[90] Gregurek, D., Reimann, C. and Stumpfl, E.F. (1998) Trace Elements and Precious Metals in Snow Samples from the Immediate Vicinity of Nickel Processing Plants, Kola Peninsula, Northwest Russia. Environmental Pollution, 102, 221-232. http://dx.doi.org/10.1016/S0269-7491(98)00090-6

[91] Caritat, P.D., Ayras, M., Niskavaara, H., Chekushin, V., Bogatyrtev, I. and Reimann, C. (1998) Snow Composition in Eight Catchments in the Central Barents Euro-Arctic Region. Atmospheric Environment, 32, 2609-2626. http://dx.doi.org/10.1016/S1352-2310(97)00463-9

[92] Franz, T.P. and Eisenreich, S.J. (1998) Snow Scavenging of Polychlorinated Biphenyls and Polycyclic Aromatic Hydrocarbons in Minnesota. Environmental Science and Technology, 32, 1771-1778. http://dx.doi.org/10.1021/es970601z

[93] Wania, F., Semkin, R., Hoff, J.T. and Mackay, D. (1999) Modeling the Fate of Non-Polar Organic Chemicals during the Melting of an Arctic Snowpack. Hydrological Processes, 13, 2245-2256. http://dx.doi.org/10.1002/(SICI)1099-1085(199910)13:14/15<2245::AID-HYP889>3.0.CO;2-7

[94] Boutron, C.F. (1991) Historical Reconstruction of the Earth's Past Atmospheric Environment from Greenland and Antarctic Snow and Ice Cores. Environmental Reviews, 3, 1-28. http://dx.doi.org/10.1139/a95-001

[95] Townsend, A.T. and Edwards, R. (1998) Ultratrace Analysis of Antarctic Snow and Ice Samples Using High Resolution Inductively Coupled Plasma Mass Spectrometry. Journal of Analytical Atomic Spectrometry, 13, 463. http://dx.doi.org/10.1039/a707871d

[96] Tranter, M., Brimblecombe, P., Davies, T.D., Vincent, C.E., Abrahams, P.W. and Blckwood, I. (1986) The Composition of Snowfall, Snowpack and Meltwater in the Scottish Highlands-Evidence for Preferential Elution. Atmospheric Environment, 20, 517-525. http://dx.doi.org/10.1016/0004-6981(86)90092-2

[97] Tranter, M., Abrahams, P.W., Blackwood, I.L., Brimblecombe, P. and Davies, T.D. (1988) The Impact of a Single Black Snowfall on Stream Water Chemistry in the Scottish Highlands. Nature, 332, 826-829. http://dx.doi.org/10.1038/332826a0

[98] Barrie, L., Lindburg, S., Chen, W., Ross, H., Arimoto, R. and Church, T. (1987) On the Concentrations of Trace Metals in Precipitation. Atmospheric Environment, 21, 113-1135. http://dx.doi.org/10.1016/0004-6981(87)90240-X

[99] Jaffe, D.A. and Zukowski, M.D. (1993) Nitrate Deposition to the Alaskan Snowpack. Atmospheric Environment, 27A, 2935-2941. http://dx.doi.org/10.1016/0960-1686(93)90326-T

[100] Shaw, G.E., Shaw, J.A. and Shaw, R.A. (1993) The Snows of Interior Alaska. Atmospheric Environment, 27A, 20912096. http://dx.doi.org/10.1016/0960-1686(93)90281-3

[101] Colin, J.L., Lim, B., Herms, E., Genet, F., Drab, E., Jaffrezo, J.L. and Davidson, C.I. (1997) Air-to-Snow Mineral Transfer-Crustal Elements in Aerosols, Fresh Snow and Snow pits on the Greenland Ice Sheet. Atmospheric Envi- 
ronment, 31, 3395-3406. http://dx.doi.org/10.1016/S1352-2310(97)00122-2

[102] Walker, T.R., Young, S.D., Crittender, P.D. and Zhang, H. (2003) Anthropogenic Metal Enrichment of Snow and Soil in North-Eastern European Russia. Environmental Pollution, 121, 11-21. http://dx.doi.org/10.1016/S0269-7491(02)00212-9

[103] Bianchini, G., Laviano, R., Lovo, S. and Vaccaro, C. (2001) Chemical Mineralogical Characterization of Clay Sediments around Ferrara: A Tool for an Environmental Analysis. Applied Clay Sciences, 21, 165-176. http://dx.doi.org/10.1016/S0169-1317(01)00086-2

[104] Hiranuma, N., Brooks, S.D., Auvermann, B.W. and Littleton, R. (2008) Using Environmental Scanning Electron Microscopy to Determine the Hygroscopic Properties of Agricultural Aerosols. Atmospheric Environment, 42, 1983-1994. http://dx.doi.org/10.1016/j.atmosenv.2007.12.003

[105] Haapala, H. (1998) The Use of SEM/EDX for Studying the Distribution of Air Pollutants in the Surroundings of the Emission Source. Environmental Pollution, 9, 361-363. http://dx.doi.org/10.1016/S0269-7491(98)00025-6

[106] Frankel, R.S. and Aitken, D.W. (1970) Energy Dispersive X-Ray Emission Spectroscopy. Applied Spectroscopy, 24, 557-566. http://dx.doi.org/10.1366/000370270774372308

[107] Wilkinson, K., Lundkvist, J., Seisenbaeva, G. and Kessler, V. (2011) New Tabletop SEM-EDS-Based Approach for Cost-Efficient Monitoring of Airborne Particulate Matter. Environmental Pollution, 159, 311-318. http://dx.doi.org/10.1016/j.envpol.2010.08.024

[108] Yang, H.H., Hsieh, L.T. and Cheng, S.K. (2005) Determination of Atmospheric Nitrate Particulate Size Distribution and Dry Deposition Velocity for Three Distinct Areas. Chemosphere, 60, 1447-1453. http://dx.doi.org/10.1016/i.chemosphere.2005.01.067

[109] Goodarzi, F. (2006) Morphology and Chemistry of Fine Particles Emitted from a Canadian Coal-Fired Power Plant. Fuel, 85, 273-280. http://dx.doi.org/10.1016/j.fuel.2005.07.004

[110] De La Campa, A.M.S., De La Rosa, J., Querol, X., Alastuey, A. and Mantilla, E. (2007) Geochemistry and Origin of PM10 in the Huelva Region, Southwestern Spain. Environmental Research, 103, 305-316. http://dx.doi.org/10.1016/j.envres.2006.06.011

[111] Fromme, H., Diemer, J., Dietrich, S., Cyrys, J., Heinrich, J., Lang, W., Kiranoglu, M. and Twardella, D. (2008) Chemical and Morphological Properties of Particulate Matter (PM10 and PM2.5) in School Classrooms and Outdoor Air. Atmospheric Environment, 42, 6597-6605. http://dx.doi.org/10.1016/j.atmosenv.2008.04.047

[112] Campos-Ramos, A., Aragón-Piña, A., Galindo-Estrada, I., Querol, X. and Alastuey, A.(2009) Characterization of Atmospheric Aerosols by SEM in a Rural Area in the Western Part of México and Its Relation with Different Pollution Sources. Atmospheric Environment, 43, 6159-6167. http://dx.doi.org/10.1016/j.atmosenv.2009.09.004

[113] Telloli, C., Coren, F., Marrocchino, E. and Vaccaro, C. (2013) Vertical Profiles of Airborne PM in Po Valley during Wheat Harvest Activities. Advances in Natural Science, 6, 1-8.

[114] Taylor, S., Lever, J.H. and Harvey, R.P. (2000) Numbers, Types and Compositions of an Unbiased Collection of Cosmic Spherules. Meteoritic and Planetary Science, 55, 651-666. http://dx.doi.org/10.1111/j.1945-5100.2000.tb01450.x

[115] Genge, M.J., Engrand, C., Gounelle, M. and Taylor, S. (2008) The Classification of Micrometeorites. Meteoritic and Planetary Science, 43, 497-515. http://dx.doi.org/10.1111/j.1945-5100.2008.tb00668.x

[116] Glenn, D.W. and Sansalone, J.J. (2002) Accretion of Pollutants in Snow Exposed to Urban Traffic and Winter Storm Maintenance Activities. Journal of Environmental Engineering, 128, 167-185. http://dx.doi.org/10.1061/(ASCE)0733-9372(2002)128:2(167)

[117] ARPA Emilia Romagna—Report sulle acque superficiali e sotterranee delle città dell’Emilia Romagna, 2009.

[118] Sansalone, J.J., Buchberger, S.G. and Koechling, M. (1995) Correlation between Heavy Metals and Suspended Solids in Highway Runoff. Journal of the Transportation Research Board, 1483, 112-119.

[119] German, J. and Svensson, G. (2002) Metal Content and Particle Size Distribution of Street Sediments and Street Sweeping Waste. Water Science and Technology, 46, 191-198.

[120] Magil, N. and Sansalone, J. (2010) Distribution of Particulate-Bound Metals for Source Area Snow in the Lake Tahoe Watershed. Journal of Environmental Engineering, 136, 185-193. http://dx.doi.org/10.1061/(ASCE)EE.1943-7870.0000146

[121] Geivanidis, S., Pistikopoulos, P. and Samaras, Z. (2003) Effect on Exhaust Emissions by the Use of Methylcyclopentadienyl Manganese Tricarbonyl (MMT) Fuel Additive and Other Lead Replacement Gasoline. Science of the Total Environment, 305, 129-141. http://dx.doi.org/10.1016/S0048-9697(02)00476-X

[122] Helmerich, B., Hilliges, R., Schriewer, A. and Horn, H. (2010) Runoff Pollutants of a Highly Trafficked Urban Road-Correlation Analysis and Seasonal Influences. Chemosphere, 80, 991-997. http://dx.doi.org/10.1016/j.chemosphere.2010.05.037 
Scientific Research Publishing (SCIRP) is one of the largest Open Access journal publishers. It is currently publishing more than 200 open access, online, peer-reviewed journals covering a wide range of academic disciplines. SCIRP serves the worldwide academic communities and contributes to the progress and application of science with its publication.

Other selected journals from SCIRP are listed as below. Submit your manuscript to us via either submit@scirp.org or Online Submission Portal.
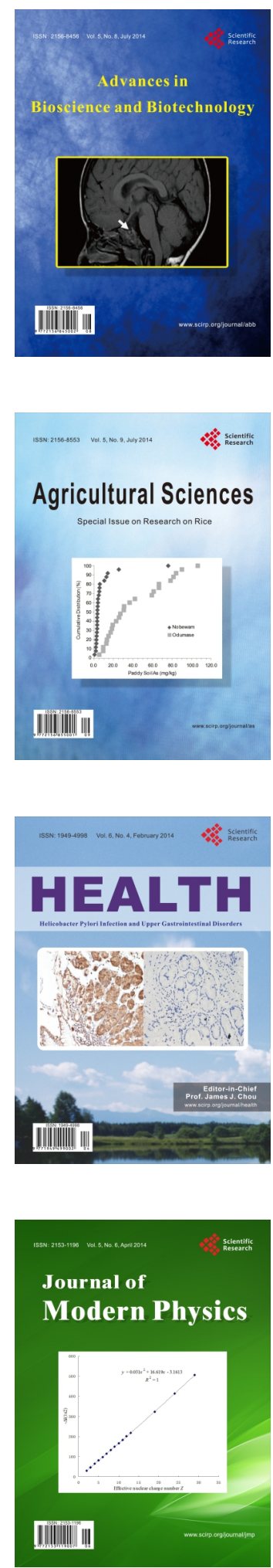
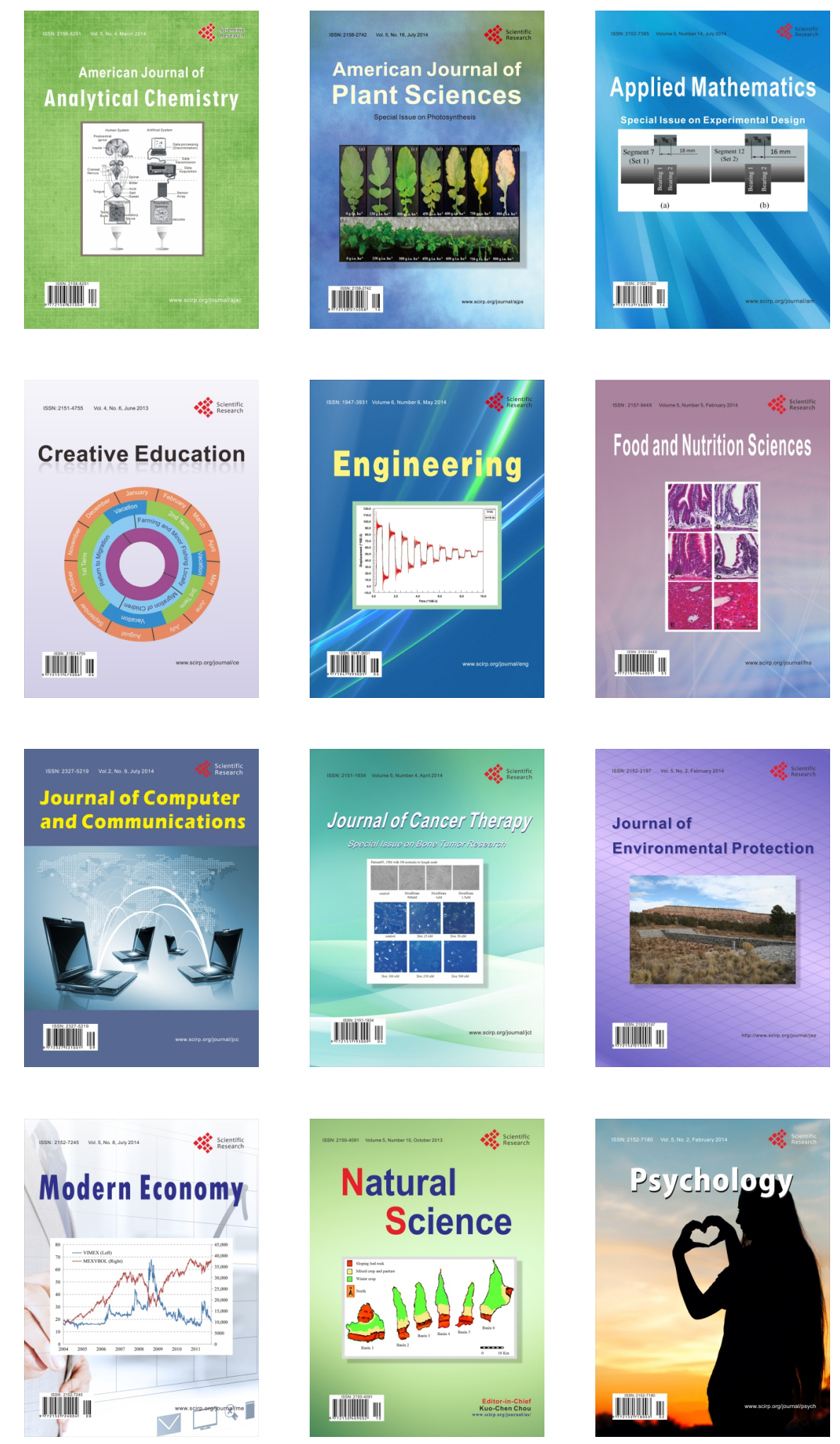